MASS. EA31.2:N42

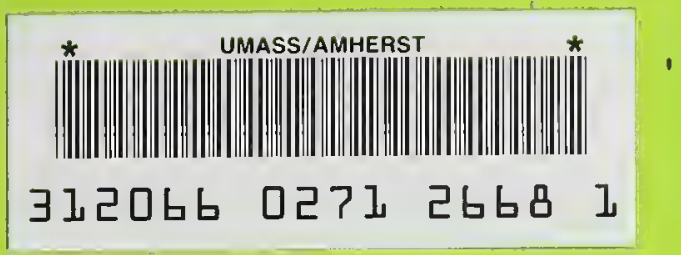

NEW ENGLAND FISHERY MANAGEMENT COUNCIL INVOLVEMENT

WITH THE MID-ATLANTIC COUNCIL'S SURF CLAM \& OCEAN QUAHOG FISHERY MANAGEMENT PLAN

\author{
David E. Pierce \\ Massachusetts Division of Marine Fisheries \\ 100 Cambridge St. \\ Boston, MA 02563
}

Funded by the New England Fishery Management Council 



\title{
NEW ENGLAND FISHERY MANAGEMENT COUNCIL INVOLVEMENT WITH THE MID-ATLANTIC COUNCIL'S SURF CLAM \& OCEAN QUAHOG FISHERY MANAGEMENT PLAN
}

David E. Pierce

\author{
Massachusetts Division of Marine Fisheries \\ 100 Cambridge st. \\ Boston, MA 02563
}

Furded by the New England Fishery Management Council Publication \#: 1323b-29-5u-5-83- C.R. Approved by John J. Manton, State Purchasing Agent 


\section{Digitized by the Internet Archive in 2012 with funding from}

Boston Library Consortium Member Libraries 
The Surf Clam/Ocean Quahog Plan was implemented by emergency regulations on November 17, 1977. This Plan set annual (January through December) catch quotas of $1,800,000$ bushels of surf clams and 3,000,000 bushels of ocean quahogs. The surf clam quota was allocated by calendar quarter with 350,000 bushels for the first and fourth quarters and 550,000 bushels for the second and third quarters. For surf clams the plan restricted fishing effort through a reduction of allowable fishing time (days fished) and, importantly, established a moratorium on new entrants into the fishery. The plan required a significant cutback in allowable harvest. It recognized that surf clam populations were declining and that a long-term stock rebuilding program was needed. It also recognized that fishing effort would be transferred to the ocean quahog resource, thus the need to manage surf clams and ocean quahogs together. Three objectives were set:

1) Rebuild the declining surf clam population to allow eventual harvest approaching the 50,000,000 pound level, which is the present best estimate of the maximum sustainable yield (MSY), based on the average yearly catch of 1960 through 1976.

2) Minimize the short-term economic dislocations to the extent possible consistent with objective 1 and promote economic efficiency.

3) Prevent the harvest of ocean quahog from exceeding biologically sound sustainable yield levels, and direct the fishery toward maintaining optimum yield.

This Plan aroused much concern by the New England Fishery Management Council (NEFMC). Ever since the Draft Plan was published in April 1977, the New England Council kept up with the Plan's development and attempted to have its recommendations accepted by the Mid-Atlantic Fishery Management Council (MAFMC), the lead Council for Plan development. In particular, Massachusetts and Rhode Island, as states and members of the Council, attempted to prevent the Surf Clam/Ocean Quahog Plan from unduly restricting existing and potential Eisheries in New England for both species. For example, soon after the proposed Plan was published, the Massachusetts Division of Marine Fisheries (DMF) related its concern to the New England Council that the proposed moratorium and quotas appeared to pertain to the New England as well as the mid-Atlantic areas. The New England Council as a whole recognized this possibility too as evidenced by an open letter, providing a summary of the Draft Environmental Impact Statement/Fishery Management PIan (DEIS/FMP) and a 
detailea analysis of regulating requirements and implications thereof, to the New England surf clam/ocean quahog industry. The New England Council took the following position on the Draft:

1) "The 35,000,000 pound quota on surf clams is not clearly and everywhere limited to the mid-Atlantic waters. In all references, both in the Plan and in the proposed emergency regulations, the surf clam quota should be rigorously defined as applying to the mid-Atlantic waters along and to the south and west of a line extending from Montauk, Long Island, southward to the 22 fathom line.

2) The controlled entry stipulation outlined as option I should read: the number of vessels in the surf clam fishery will be frozen in the mid-Atlantic area six months from the date of enactment of the Management Plan with consideration of limitations in the New England area at a later date.

3) While the text clearly anticipates workweek restrictions as applying only to the mid-Atlantic waters, this fact is not clearly stated everywhere. Again, a line separating the mid-Atlantic region from the New England region is needed. All restrictions contemplated should be clearly listed as applying to waters to the north and east or to the south and west of the line.

4) In general the Council supports the Plan as being urgently needed, contingent upon clarification of regional restrictions."

On July 25, 1977, the Executive Director of the New England Council sent to each member a copy of the Final EIS/ FMP which had no geographic distinction between the New England and mid-Atlantic areas. The moratorium applied to both regions and was to:

"Prohibit the entry of additional vessels into the surf clam fishery effective immediately upon the adoption of the Plan by the Secretary of Commerce. This provision would not exclude those vessels demonstrated to have been under construction at the time of adoption of the FMP. The moratorium would not preclude replacement (with a vessel of similar capacity) of vessels involuntarily leaving the fishery during the time when the moratorium is in force: other hardship cases would be considered on a case by case basis according to criteria recommended by the Council and prescribed by the secretary. The FMP recommends that the moratorium remain 
in effect for one year from the date of adoption of the FMP unless the Secretary determines, after consultation with the council and after a public hearing, that the moratorium should be terminated or extended."

The FEIS/FMP also established a four-day workweek, Monday through Thursday, to help spread yearly catch evenly throughout each quarter.

On September 21, 1977 representatives of the New England and Mid-Atlantic Councils, National Marine Fisheries Service, Massachusetts Division of Marine Fisheries, Rhode Island Division of Fish and Wildlife and Maine Department of Marine Resources met to review and resolve questions related to final objectives and proposed regulations of the surf $\mathrm{Clam} /$ Ocean Quahog Management Plan. The two principal points of concern were:

1) the stated objective of stabilizing the surf clam stock, and;

2) the one-year moratorium on new entry into the surf clam fishery immediately upon implementation of the Management Plan.

According to a summary of the meeting,

\begin{abstract}
"There was extended discussion on the issue of immediate restricted entry. The point was stressed that the restriction would preclude any New England vessels from exploring for or fishing on any surf clam stocks off the New England coast including those vessels that presently had an interest or intent in doing so. It was made clear that the New England Council did not propose that New England vessels would fish off the mid-Atlantic coast, nor that mid-Atlantic vessels would be precluded from fishing off New England.

After extended discussion on the feasibility of of establishing zones in which the moratorium on entry would and would not apply, the Mid-Atlantic Council agreed it would recommend a line off the Long Island/Connecticut coasts, east of which the restricted entry proposal would not apply."
\end{abstract}

This line was included in the FEIS/FMP so as to prohibit the entry of additional vessels into the surf clam fishery south of $41^{\circ}$ latitude. However, when emergency, proposed, and final regulations were published on November 17, 1977, 
January 3, 1978, and February 17, 1978, no line of demarcation for entry moratorium was included.

The removal of the line from the FEIS/FMP prompted Allen Peterson, then Director of DMF, and Jay Cronin, Director of the Rhode Island Division of Fish and Wildlife, to send protests to then Assistant Administrator for Fisheries, Terry Leitzel (see letters).

A March 6, 1978 response (see letter) to Rhode Island's protest indicated that NOAA attorneys felt the two areas (north and south of $41^{\circ}$ latitude) could not be established since it would have been possible for a vessel to be built north of the line and then legally moved south.

An April 12, 1978 response (see letter) to Massachusetts' protest was received from Terry Leitzel. Reasons for not exempting the New England area from the moratorium and the four-day workweek were given. These reasons were:

1) The Mid-Atlantic Plan contained no documented analyses or justification for such an exemption and no analyses or documentation of the impact of possible options.

2) No evidence of the substance or conclusions of discussions to exclude the New England area from the moratorium was presented for the record in the Plan or in supplemental material.

3) No provision for public comment on the proposed exclusion was made.

4) NMFS legal and enforcement people felt that the exclusion, as written, was unenforceable.

The issue was pursued further by Allen Peterson, and he received another reply (see letter) which indicated that "a number of significant legal issues" needed to be examined regarding the moratorium issue.

Because the Plan was implemented, the only way to accomodate New England concerns was through a formal Plan Amendment. In keeping with this stipulation the New England Council contacted the Mid-Atlantic Council and requested an Amendment (see June 13 letter). The NEFMC,

1) Understood that the Mid-Atlantic Council intended to hold public hearings in July on an Amendment to the Plan. 
March 6, 1978

U.8. DEPAATMENT OF COMMERCE

Netional Deeenic end Atmosphoric Administretion NATIONAL MAHINF FISHEAIES SIRJILE

Northeast Region $31: 1, ;$

Fisheries Management Division

State Fish Pier

Gloucester. MA $01930 ;$; $\therefore$.

Mr. John M. Cronan, Chief

Rhode Island Division of Fish and Wildlife

Box 37

West Kingston. RI 02892

01, ing:

Inis is in response to your letter of Febriary 13 outlini i problem area: if inf: vurf clam regulations currently in c:iect. The refilaticns fur thnsi. .nneles protected under the Fishery conservation an I Manacuement Art are wised cn the inforiulion and jurisdictiuns develoned in the species "Iran. that lie lipli,milation used in preparing the plan was inter l.eted as desc-ibing the entire range of the resuurce, rather than the lim. "ed ired envisioned hy the surf clall technical committee. Lawyers decided th, could nos be sevarated. Apparently it would be rossible to bulld a ve sel and fish it north of $41^{0}$ tror awile and then leqally move soutr. lind. the systein of

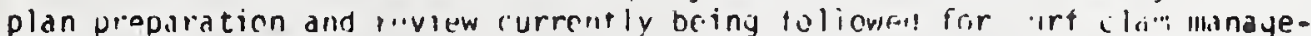

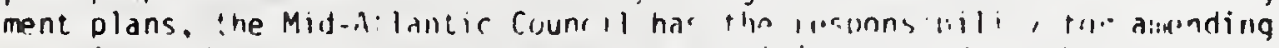

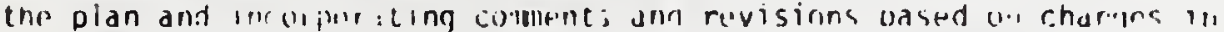
stock dssessurent ar plan, ine industry explan ind

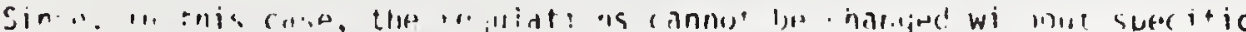

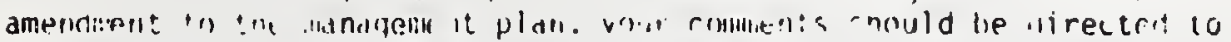

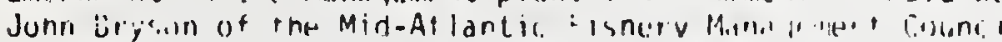

sincere $! y$.

Finitu ut lite

(hil. : isharies Manigament Oivisinn

Lnı $1 \ldots, 1.1 \mathrm{e}$ 


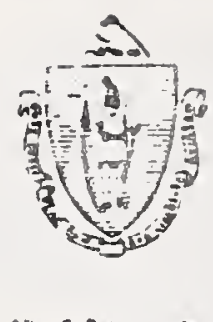

The Gommonusalth of ellabuchusetts

Division of Mlaxine Fisheries

Leverett Sallonstall Sinte Cifice Building

100 Canbridge Sireet. Puciton C22C2

Bontor

Eebruary 3, 1978

Mr. Terry L. Leitzell $E$

Assistant Administrator Eor Fisheries

National oceanic and Atwospheric Administration

3300 whitehaven Darkway, Niw

kashington, D.C. 20235

Dear Mr. Leitzell:

The Massachusetts Division of Marine Fisheries on behalf of the fishermen of our state wishes to comment on the proposed surf clam and ocean quahog regulations as publisied is the Federal Register (Volume 43, No. 1) dated Janliary 3. 1978.

In particular, the goratorium on entry into the surf clan fishery within the entire Fishery Conservation zone (section 652.91; paragraph a) is of great concern. On September 21,1977 , in Peabody, Massachusetts, Iepresentatives of the liow England and Mid-Atlantic Fishery Maragerent Council, the National Marine Fisheries Service, and the Massachusetts Division of larine Fisheries met to specificallv ciscuss the 'broposed r.szatoziun. It was agreed that the 2:id-Atlantic Council would reconread a line of demarcation ofe the long Island-Connecticut coast east of which the moratorium would not apply. The reasons $f \circ=$ the decision were: I) in our region the abundance and distribution of surf class is unknown and the stocks are vi=tulily unexploited: 2) restrictions in our region would inhibit further exploration for and fishing on surf clam stocles: 3) interest in the fishery by fishermen is increesing and restrictions wculd prenaturely strangle its development.

It is realized that rejection of this amendment to the plan by the iational :arire Eisheries Service end Degertint of comnerce was brought about by legal time constraints. Horever, we feel it is ar issue of significant importance that needs to be incorporated into the plan for the renainder of 1978 .

We also nbject to the four day effort restriction (section 652.7: paragraph a). This linitation unnecesarily इzevents New England vessels from operating in a secment of the surf clam fishery which is notovercapitalized or overfist.ed.

In sumary, we do not believe these restrictive measures are necessary in the New England area.

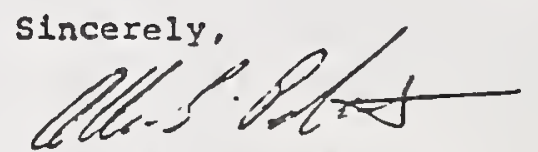

Alien E. Péterson, JI.

Director 


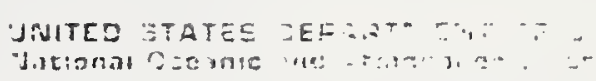

F $31 /$ RKO

\section{$\operatorname{IPT} 12978$}

Mr. Allen E. Peterson, Jr.

Director, Division of Marine Eisheries

Leverett Saltonstall state office Building

100 Cambridge Street

Boston, Massachusetts 02202

Dear Mr. Peterson:

This is in response to your letter of February 3, 1978 , concerning the regulations for the surf clam and ocean quahog fisheries in the Atlantic. Please excuse our delay in responding, but we have been obtaining clarification from the concerned parties on the points which you raise.

There were four reasons besides "legal time constraints" behind the decision not to exempt the New England area from the proposal for a moratorium on new entries into the surf clam fishery. First, the plan contained no documented analysis or justification for such an exclusion, and no analysis or documentation of the impacts of possible options. Second, although we realize that some discussion of the subject had taken place, no evidence of the substance or conclusions of these discussions was presented for the record, either in the plan, or in supplementary material. Third, there had been no provisjon for public comments on the proposed exclusion, although the subject is important and somewhat controversial. Finally, our legal and enforcement people felt that the exclusion, as written, was unenforceable due to the lack of clarity in items such as the definition of "new" clam beds, the rights of clammers from one portion of the Fishery Conservation zone (FCZ) to fish in other portions, as well as several other provisions of the exclusion. All four of these factors also apply to the exclusion of New England from the fourday workweek provisions contained in the plan.

We agree that it may be desirable to address differing situations with respect to the harvest of surf clams in the various areas of the FCZ in both the management plan and in the regulations. If you have access to data or information which might aid the Mid-Atlantic and New England Councils and our NMFS Northeast Regional office in developing an approach to this problem, please provide it to the Council.

Thank you for advising us of our concerns. The management planning process is an iterative one. Many of these problems will be ironed out as more information becomes available, and as we gain more experience in applying this information to specific problems.

Sincerely,

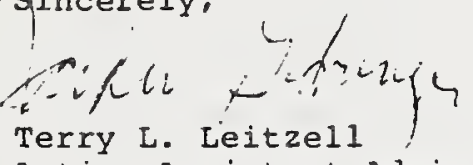

Acting Assistant Administrator ior Fisheries 
$\mathrm{F} 31 / \mathrm{MZ}$

\section{JUN $8 \quad 1978$}

Mr. Allen E. Peterson, Jr.

Director, Division of Marine Pisheries

Leverett Saltonstall State Office Bulldiag

100 Cambridge Street

Boston, Massachusetts 02202

Dear Mr. Peterson:

As was discussed in your conversation with Mark 211 berberg in our office of P1sher1es Management on Thursday, May 25, 1978, the 1ssues of the surf clam-ocean quahog moratorium and flshing effort restriction, and their impact on New England fishermen, are currently belng reviewed. I an aware of the effect of the present regulations on New England

fishemen and related problems such as vessel financing and the accurate reporting of harvest locations (1.e., 1nside or outside of the three mile limit). I anticipate that these problems will be resolved to the satisfaction of all concerned.

The comments on the surf clam-ocean quahog regulations which were mailed from your office on February 6, 1978, arrived at this office on Feb ruary 15, 1978. No exceptions were made to the February 11, 1978, deadine for recelving such comments for acknowledgment in the Federal Reg1ster.

General Counsel has Indicated to us informally that the proposai to except New England fishemen from the moratorium presents a number of significant legal issues which certainly need to be examined. This renains to be done.

You also ralsed the issue of fishing periods. While your comments regarding the moratorlum were the only coments recelved on that issue, a number of commentators raised the flshing perlod issue consonant with your views. Those coments are reflected in the final regulations.

I have asked General Counsel to exanine the legal 1 ssues referred to above. I an also asking B111 Gordon to discuss this matter with the New England Council at the earliest opportunity so that all issues are considered.

In the meantime, I appreclate your patience.

Sincerely,

C.

Terry LD Leitzell

Aasistant Administrator

for Fisheries 


\section{New England Regional Fishary Management Council}

Peabody Office Building

One Newbury Street

Peabody. Massachusetts 01960

617.535 .5450

FTS 8.223 .3822

June 13, 1978

Mr. John C. Bryson, Executive Director

Mid-Atlantic Fishery Management Council

Federal Building, Room 2115

300 South New Street

Dover, Delaware 19901

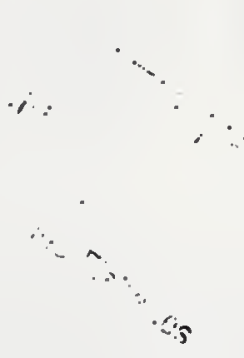

Dear John:

It is our understanding that the Mid-Atlantic Council plans to hold public hearings on amendments to the Surf Clam Management Plan in July.

This Council is very concerned about the application of management measures, which may be appropriate for the Mid-Atlantic area, to the surf clam fishery of New England. Quite different circumstances exist in the New England fishery.

This Council is concerned particularly that the resource off New England is not over-exploited, that in fact it is not adequately described or assessed, and that the fishery is hardly developed. The Council feels, therefore, that it is inappropriate that the vessel moratorium and the restrictive weekly trip limitations should apply in New England waters, and that in fact they may prevent the development of a viable New England surf clam fishery.

The public hearings that were held a year ago, particularly in Newport, RI. discussed these concerns at length. As a result of those hearings and the nature of the New England fishery, the Council urged that New England be exempted from those restrictive management measures.

It was the understanding of the Council that New England was exempted when the Surf Clam Management Plan was submitted last fall. The Council was of course disturbed to learn that all the restrictive provisions of the plan apply to the New England fishery. Therefore the Council requests that the plan be amended to include a demarcation line, east of which the vessel moratorium, catch quotas, and effort restrictions on surf clams shall not apply.

In short, the Council believes that such restrictions are unnecessary and inappropriate in New England waters where the resource is poorly known or assessed but very likely underutilized, and where the fishery is little developed and under-capitalized.

The Council therefore requests that this letter be entered as part of the record of your public hearing on amendments to the surf clam plan, and that the plan be amended accordingly.

Thank you.

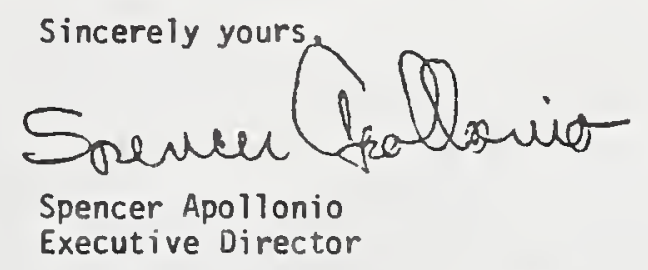

$P P$

CC: NERFMC Members 
2) Restated the New England concern over the moratorium and fishing-day Iimitations.

3) Understood that New England was exempted in the Plan submitted in the fall of 1977 (but wasn't when final regulations were implemented) and requested a Plan Amendment to include a line of demarcation north of which the moratorium, catch quotas, and effort restrictions on surf clams would not apply.

4) Wanted these New England Council comments to be entered as part of the record for the upcoming July hearings.

Frustrated by the Mid-Atlantic Council's failure to hold anticipated public hearings on the moratorium issue, the New England Council wrote Terry Leitzel on August 15, 1978 to request a secretarial hearing. A september 18 hearing was scheduled. However, just prior to this hearing the MidAtlantic Council informed the New England Council that it was considering changes to the Plan and that a draft of those changes would be discussed at an April 19, 1979 hearing. Also, NEFMC was informed that the Mid-Atlantic Council Scientific and statistical Committee was to provide recommendations for a line of demarcation.

At the September 18 hearing, the Massachusetts Division of Marine Fisheries again protested inclusion of New England in the surf clam fishery moratorium on entry (September 18 correspondence). The Division stated that a continuation of the moratorium for another year would be a further injustice to Massachusetts fishermen.

On October 19, 1978 a letter from william Gordon, then Regional Director of the National Marine Fisheries Service, was received by the Council. William Gordon provided his staff's review of the various drafts of the Plan with respect to inclusion of the New England area under the moratorium. His conclusion was that the Fishery Management Plan, approved by the Secretary of Commerce, did not exempt the New England area from the surf clam vessel moratorium even though the language both in the Draft FMP/EIS (April 1977) and the Final FMP/EIS indicated that such an exemption was the Mid-Atlantic Council's intent at that time.

In reply, the New England Council sent an October 26 letter (see letter) to then Secretary of Commerce Juanita Krebs informing her that, "the Atlantic surf Clam Plan in its present form is unsatisfactory and unacceptable to this Council and it cannot support the Plan. The council, therefore requests that you direct the Mid-Atlantic Fishery Management Council, the lead Council for this Plan, to amend the Plan as appropriate for conditions in the New England area, and that you review and promulgate regulations that will implement satisfactory and reasonable Amendments to the Plan." rhe councij finally lost its patience and made the decision to withdraw its support for the existing plan. 


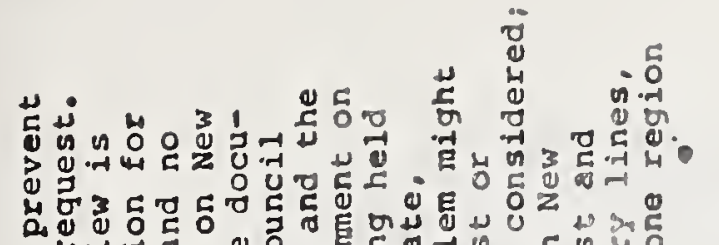

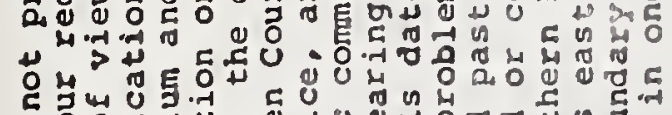

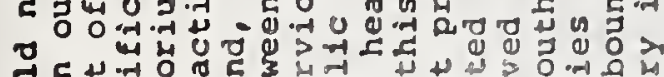

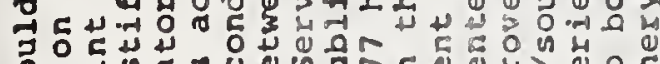

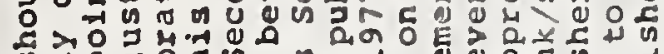 ที नो ซึ है

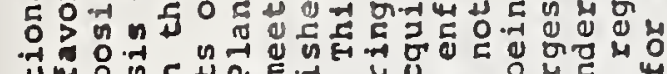 蛙

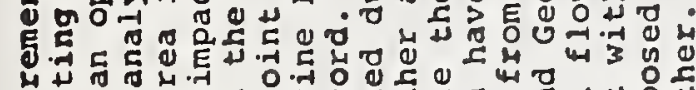

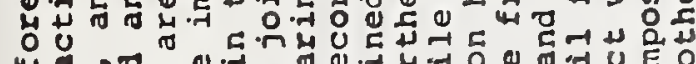

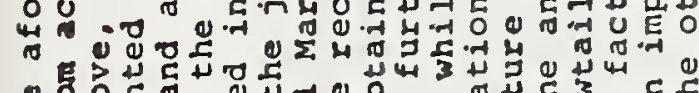

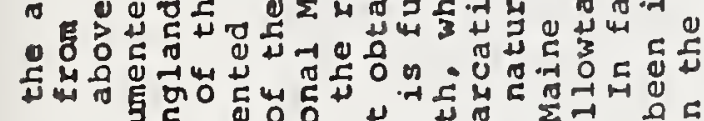 د。

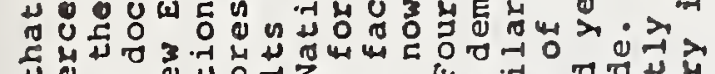

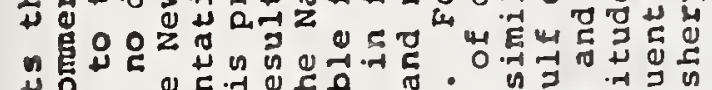 ज्ञ 0 व

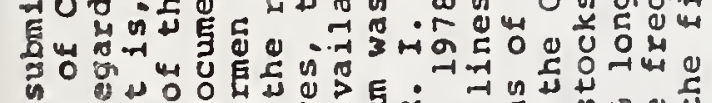 क > 政出 .

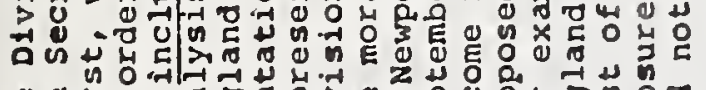

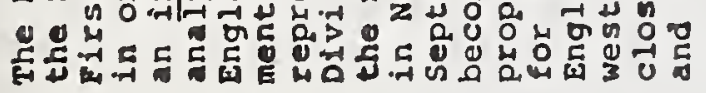

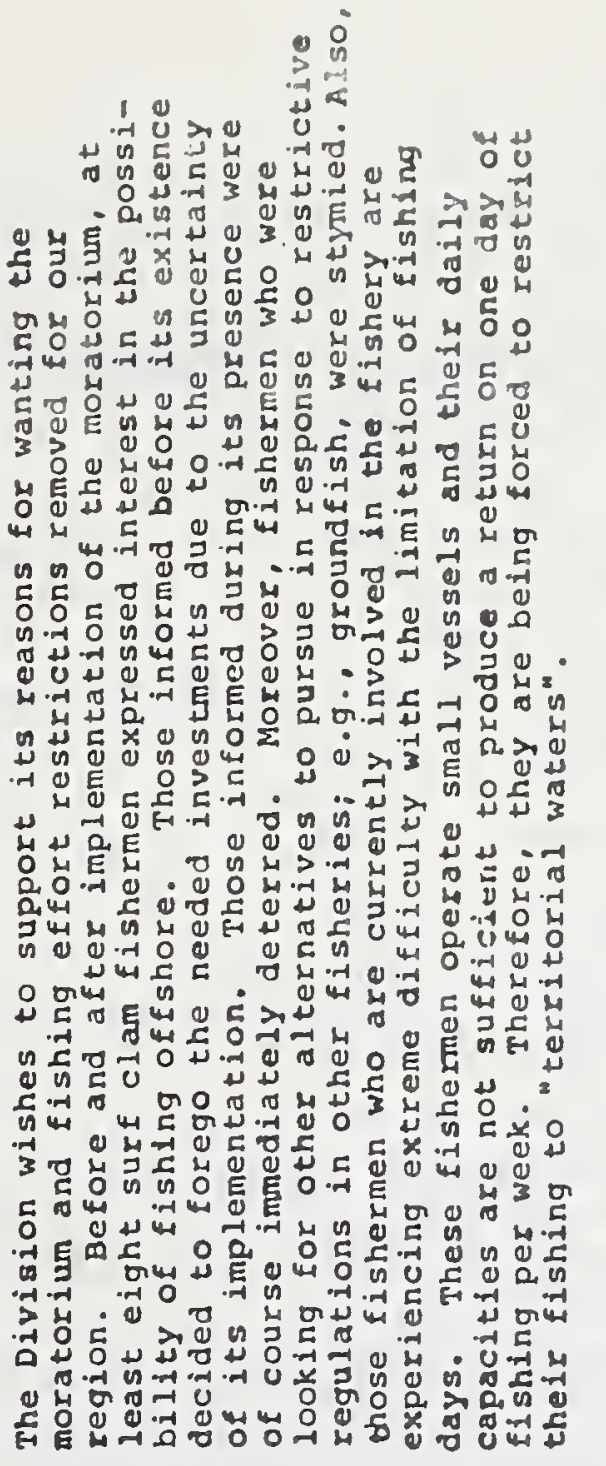

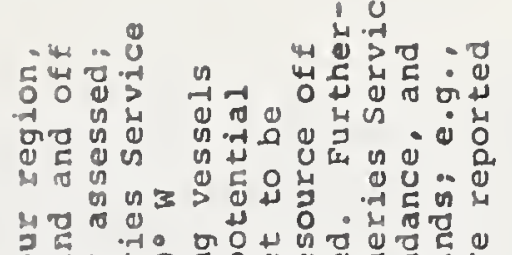

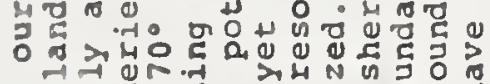 न

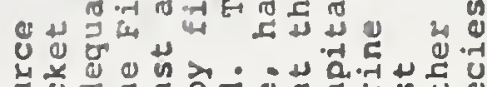

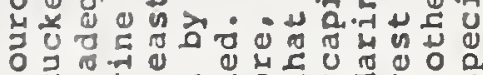 in

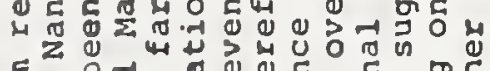

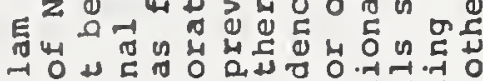

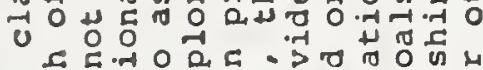

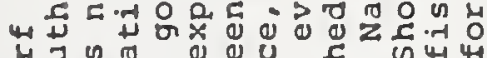

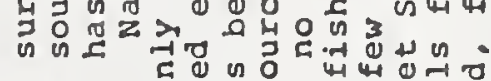

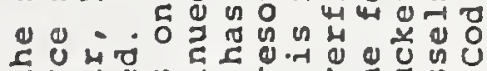 मे

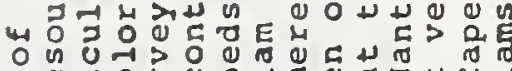

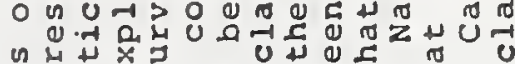

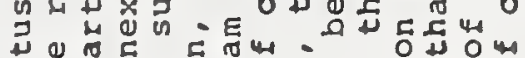

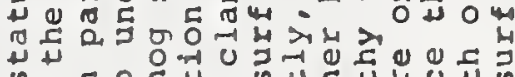 को

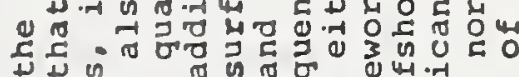

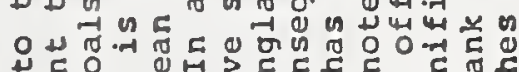

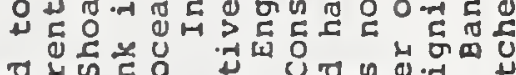

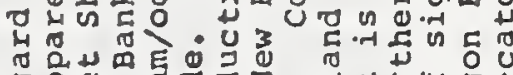 \%ํ. t

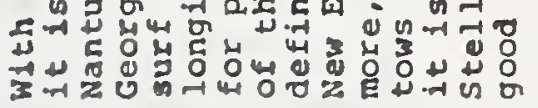

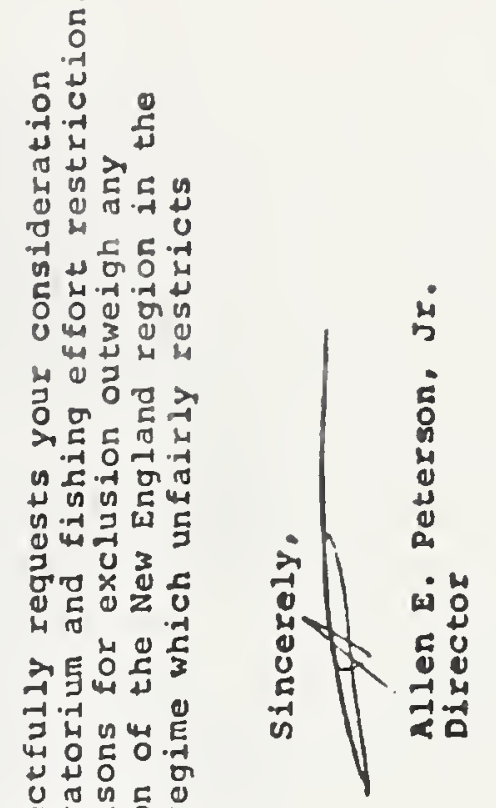

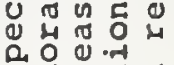

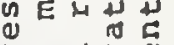

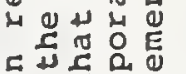

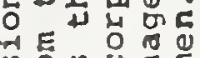

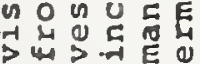

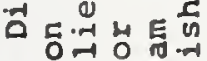

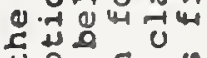

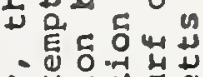

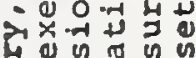 हn. 实舟出

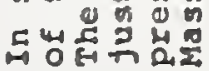

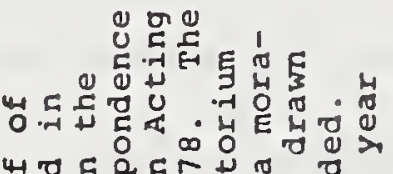

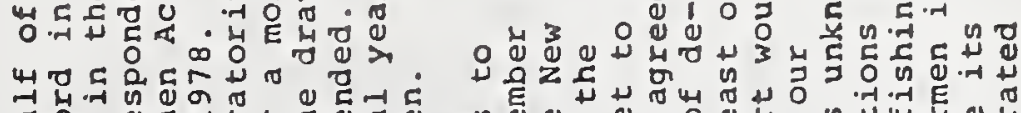

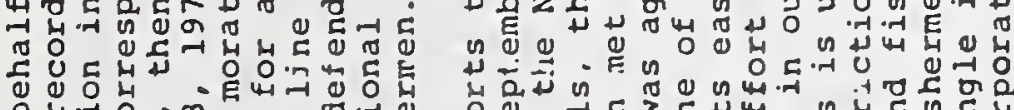

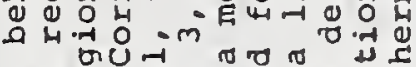

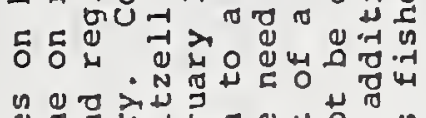

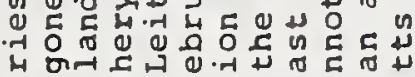
मुन

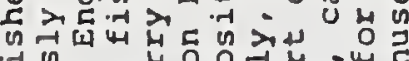

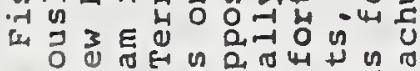

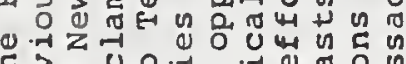
年造造出

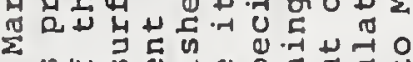

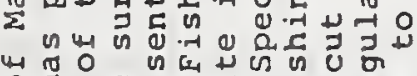

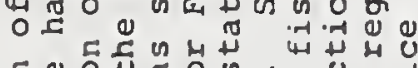

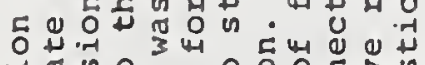

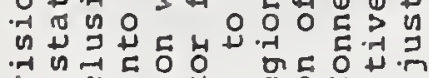

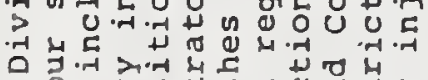

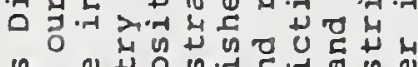
in $\begin{aligned} & 0 \\ & 0\end{aligned}$

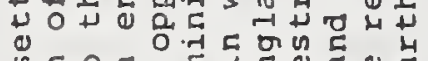

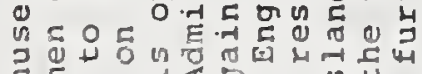

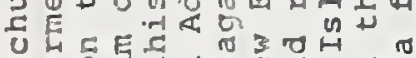

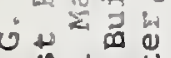
E $\rightarrow-1,0$

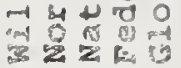

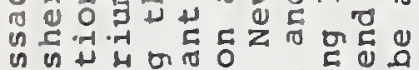

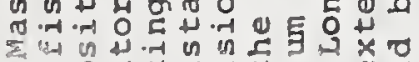
c.

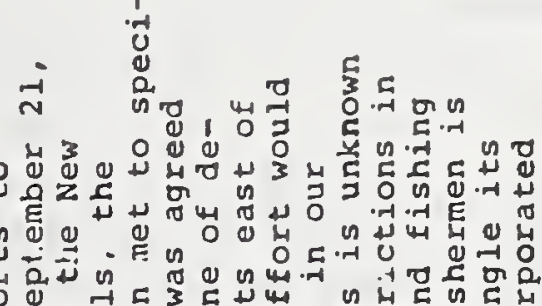

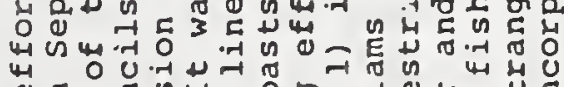

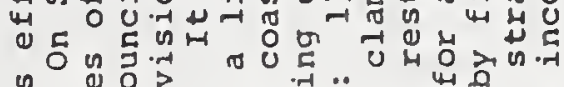

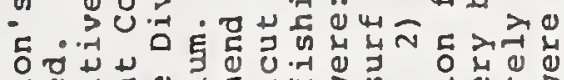

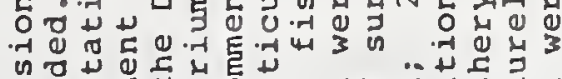
$\rightarrow$ d

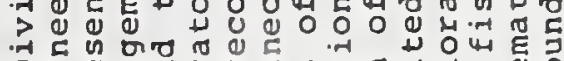
的致品出

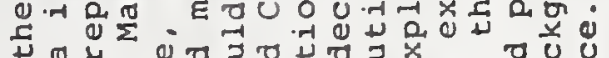

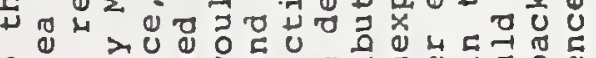

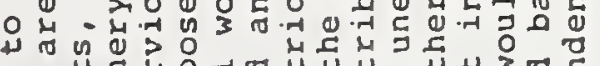

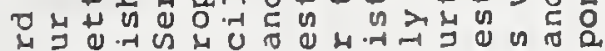
कु ब.

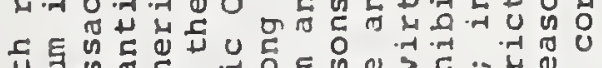

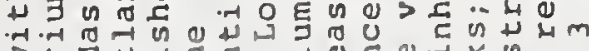

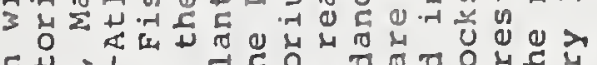
石 .

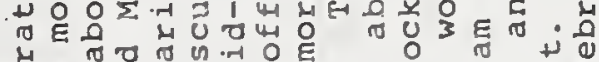

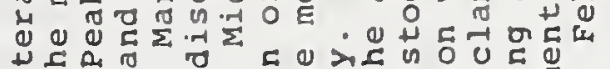

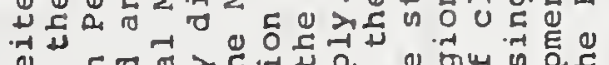

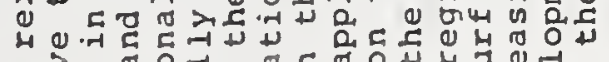
1 0

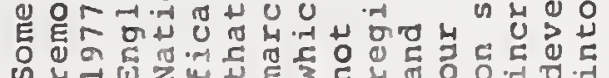

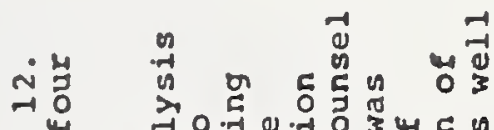

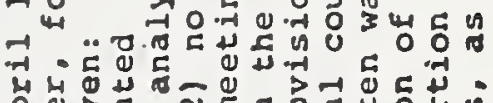

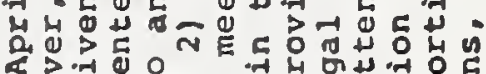

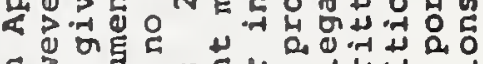

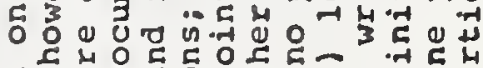
-

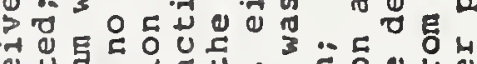

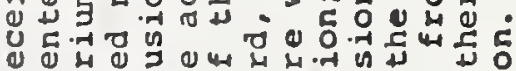
4 जु of

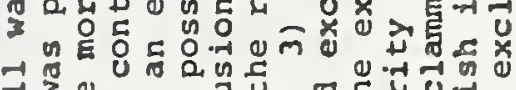

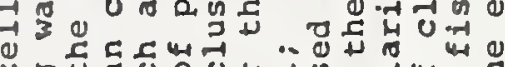

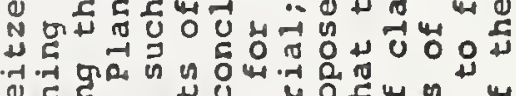

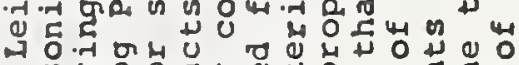

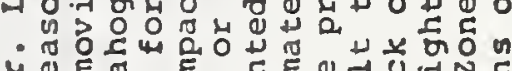

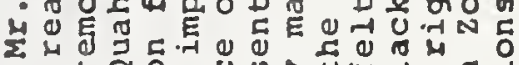

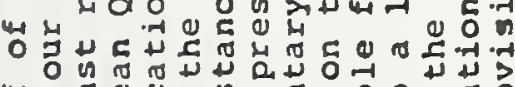

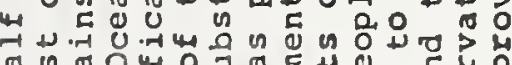

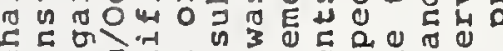

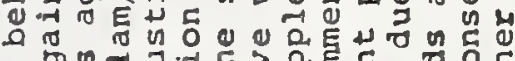
ᄃำ

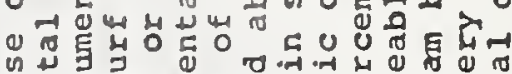
ज出

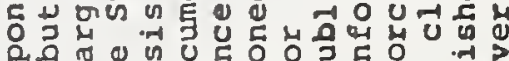

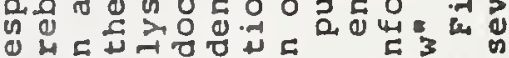

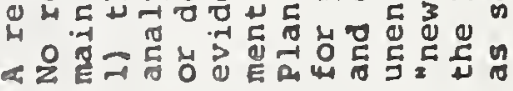


New England Fishery Management Council

Peabody Office Building

One Newbury Street

Peabody. Massachusetts 01960

617.535 .5450

FTS $8 \cdot 223-3822$

October 26, 1978

The Honorable Juanita Kreps

Secretary

Department of Commerce

Washington, OC 20230

THRU: Terry Leitze11, Asst. Administrator for Fisheries, NOAA/NMFS

Dear Madam Secretary:

This Council wishes to express, once again, its serious concern with the Atlantic Surf Clam Management Plan which extends a vessel moratorium and other severely restrictive regulations to the surf clam fishery in the Fishery Conservation Zone off New England.

There is an extensive and readily available record at this time, including more than one public hearing, letters from this council, minutes of public meetings of this Council, minutes of joint committee meetings of the New England and Mid-Atlantic Fishery Councils, letters from concerned state fisheries agencies, and letters from industry representatives, on the total impropriety of those regulations to the actual conditions of the Surf Clam fishery off New England. I will not repeat the details or ficts of that record in this letter, but only point out, once again, that it irrefutably documents that no good or valid purpose, within the context of the Fishery and Conservation and Management Act of 1976, is served by those regulations.

This Council has repeatedly and patiently requested that this situation be corrected. This has not been done.

The Council wishes to inform you that the Atlantic Surf Clam in its present form is unsatisfactory and unacceptable to this Council, and it cannot support the plan. The Council, therefore, requests that you direct the MidAtlantic Fishery Management Council, the lead Council for this plan, to amend the plan as appropriate for conditions in the New England area, and that you review and promulgate regulations that will implement satisfactory and reasonable amendments to the plan.

This Council will be pleased to cooperate fully with the Mid-Atlantic Council, NOAA, and the National Marine Fisheries Service in developing reasonable amendments to the plan and appropriate regulations. It looks forward to learning of your intended action on this issue. Thank you.

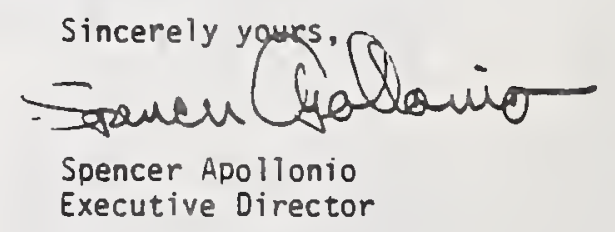

$S A: j r$

ce: Mr. Terry Leitzell

Mid-Atlantic Council 
To the New England Council's chagrin, on November 22, 1978, the moratorium was extended for an additional year. The Federal Register announcement describing the rationale for this extension is provided here. The announcement also summarizes the changes in fishing-day restrictions during the first year of the Plan's implementation.

At January 1979 Council meetings the status of the surf Clam Plan was related. The question of the New England exemption from the entry moratorium was left unanswered. The Mid-Atlantic Council was exploring different means of controlling effort in the surf clam fishery for 1980 and NMFS felt that any amendment to exclude the New England area in the interim period would:

1) result in a loss of the moratorium in the midAtlantic as well as in New England;

2) need substantial analyses and an environmental impact statement, thus much work and delay:

3) result in three concurrent amendments involving considerable, perhaps overpowering, staff work and administrative procedures;

4) not be developed and formalized before the scheduled implementation of the new Plan (January 1, 1980).

Some interim relief was expected in the form of a relaxation of the number of allowable fishing days north of $41^{\circ}$ latitude (line from off Montauk, Long Island to $141 / 2$ miles south off Nantucket Island). However, there was still no assurance that the New England region would eventually be excluded from the entry moratorium. Consequently, the council asked NOAA Counsel to determine if litigation was an appropriate course of action.

NOAA Counsel's summary of the administrative record of the Surf Clam/Ocean Quahog Fishery Management Plan and his opinion on litigation were provided (see February 6 memo). He did not recommend litigation since:

"There can be little doubt that the administrative record is so complex that the legal and factual issues to be argued on your behalf will require extensive and expensive preparation. Further, once the Council would be in a position to go to court, judicial procedures themselves would be so slow as to eliminate the possibility of timely relief. Aso, the court is likely to take account of the pending revision of the Plan in fashioning a remedy; and may delay action to see what the Mid-Atlantic council comes up with." 

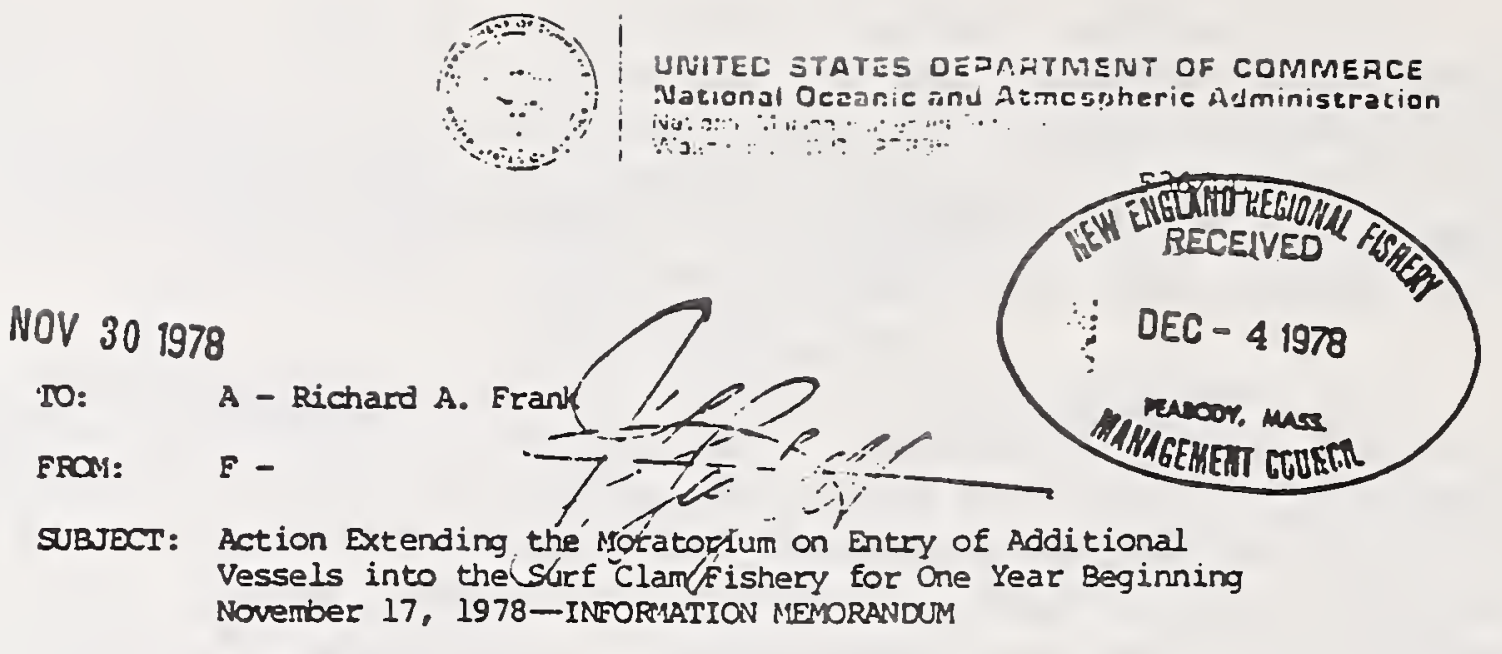

Regulations implementing the Fishery Management Plan for the Surf Clam and Cccan cuatog Fisheries (EMP) contained a moratorium provision which prohibited additional vessels from entering this fishery for a one year period ending November 16, 1978. The Mid-Atlantic Fishery Hanagement Council, which is the lead Council for this FMP, has requested a one year extension of this moratorium. I have taken action to amend the regulations implementing this plan to meet this request.

There has been significant controversy over the inclusion of the New England region in this moratorium. The New England Fishery Management Council has expressed strong opposition to both the National Marine Fisheries Service and the Mid-Atlantic Council to the moratorium being applied to the surf clan fishery in the New England area. The Council's basic position is that the inew England resources are currently underdeveloped and no moratorium is necessary.

The Mid-Atlantic Council continues to support the moratorium throughout the entire surf clam fishery covering both the Mid-Atlantic and New England areas. The Council anticipates taking action in 1979 to develop an alternative strategy that would solve the problem of entry and exit in this fishery. "Until a final strategy is developed, the Council does not want additional vessels entering the New England fishery because it feels that such vessels could then gain legal rights to the overcapitalized inid-Atlantic surf clam Eishery under the present management regime. "

I an extending the moratorium despite the controversy, since exempting the New England area from the moratorium would require a plan amendment with due public process. The Mid-Atlantic Council, after considering testimony at two public hearings, recommended continuation of the moratorium in both areas.

The Northeast Regional Director, who is a voting memiser on both the New England and Mid-Atlantic Councils, is currently discussing possible olan amendments with the Mid-Atlantic Council to resolve the difference between the two Councils on this question. However, the Mid-Atlantic Council may choose to defer action to amend the plan until an alternative management scheme is developed.

CLEARANCES

DATE

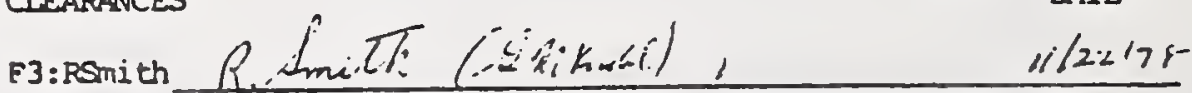

GC:EGreenberg

PP:MGlazer

A: Jwalsh

Prepared by: D.Leedy, NMFS, 634-7436, 11/21/78 


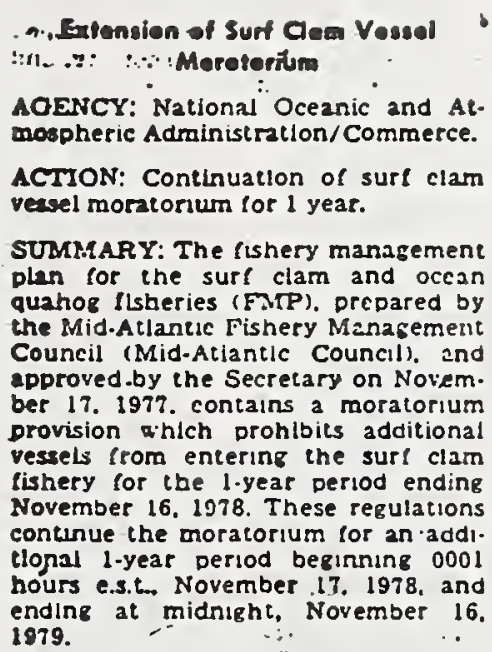

EFFECTIVE DATE: 0001 hour e.s.t. November 17. 1578.

FOR FURTHER INFORMATION CONTACT:

Mr. Denton Moore: 202-634-7454.

SUPPLEMENTARY INFORMATION: Pursuant to section 305 of the fishery Conservation and Management Act of i976 (16 U.S.C. 1801 et scc.). tinal resu. latlons were published on February 17. 1978 (43 FR 6052). to implement the FMP prepared by the Mid-Allanlic Council and approved by the Secretary of Commerce for the surt clam and ocean qua hog fisheries. Section 652.9 of chose regulations pronibits the entry of additlonal vessels into the surf cla

- Ishery until November 16. 1978.

The FMP soccifles annual quotas for the harvesting of surf clams for the 2 years in which the EMP is to be in effect with these quotas allocated on a quarterly basts. The sur! clam annua! and respective quarterly quotas are the same for each of the 2 years lor which the Council specilled an optimum yield for the surf clam resource.

In the lirst year of this FMP. the following actions were laken to insure that the guartcrly quotas were notex. ceeded:
Io the flrst quarter of 1978 the nsh. int period was limiled to 4 days Der week. Monday-Thursday. The quarter. ly quota was obtanned by March 10 and the flshery closed untll April 1.

Ellort in the second quarter was initially restricted to 48 hours per rieek and then 24 hours per week to prevent the quota from being exceeded.

In the thlrd quarter. the 24-hour. Der-week rlshing period was continued.

For the fourth cuarter of 1978 . fishing period of 36 hours per rieek a.2s originally specifled. This extension was based on a "cirry-over" of the uncaught part of the quota for the third cuarter. and expected adverse weather condtions. The third quarter quota was not reached and the surplus of $\mathbf{3 7 . 8 3 4}$ bushels has been added 10 the fourh quarter guola for a total quola of 387.834 bushels for this qua ter. The rishin- Deriod 0.39 reduced to 24 hours on October 30 due 10 the rapid rate ol exploitation.

Judgine by the actions taken durin the first year in thich the FarP has been in eflect. there is no Indicatio that the number of vessels permitted to hiriest surf clams is insufficlent to achicve alloxiable quotas. The need to signiflcantly limit tishing eflort during 1978 strongly sucgests that the harvesting canacity of the fisling flect easily exceeds the specificd quotas. The economic impacts that would rcsult fiom additional ves.sels cnterin his / ishery are unchanged trom those presented in the FMP.

Th: New England Fishery Manage. ment Councli (New England Couticil) : obiects strongly to including the NC Encland area ln a surf clam vessel moratorium. Hearings were held on Septemoer 14 and 18. 1978 lo obtain publie comment on the nroposal to continue the moratoriuin. The New Eng and Council commented that the Fal' should be amended to remose the very small New England lishery trom the moratorium restrictions 2.5 Counell recornizes the need for a mor. atorium in the overcapitaluged side. lantie flshery. but feels strongly that the New cher co the development or the hishery and has caused particular hardship to the rea's tishermen. Most of these surf clans are caken irom terrtorial wacers clare the chicl use or surf clams taken.in the New England arca is bait for recreational tishing.

The Fis provides that the secre. ary of Commerce may contunue the moratorium for 1 additlonal year be Inning Noyember 17. 1978. The As sistant Administrator for Fisheries has determined hat he moratorlum shall be continued and this document con inues the moratorium oy amendine the regulations which impiemented the FMIP. All procedural requirements or this action have been rurrilled. Continuation of the moratorium in only the area south or the 4 lst paral el. as recommended by the New Ens. land council can be accomplished only by an amendment lo the FMP. The FMlP has nol been aniended to ac complish this. Theretore the morato rium must be coirtinued in the cntire area or it must lapse. The Assistant Administrator delermines that the surf clam vessel moralorium is continucd for a period of I year beginning a 0001 hours e.s.t.. November 17. 1978. and ending on nudnight. November 16.

The Asslstant Adminlstrator further linds and determines chat this is not significant Fedcral action rithin the meaning of the National Enitronmen (a) Policy Act and does not require Complinnce Qillh Exrecultue Orders 12044. 11821. and 11949

116 U.S.C. 1801 et sta.s

Signed at Washington. D.C.. this the 6 th day of November 1978. - Wintred H. Metzoha.

Notional Manne Fisheres Serice.

Amend 50 CFR Part 652 to revise 652.9 to read as follows:

1652.9 Vessel muralurium.

(a) A moratorium which becane ef enber 17. 197\%. Drohib. lics ene entry or additiona the surf clam hishery.

(b) The moracornin shall remain in ellect uncil Noveruber the Secretary detcrmines. after publle hearnas and constilation with the Melatlantic. New Eligland, and South cils. to terminate the moratonuns at on earller date. 


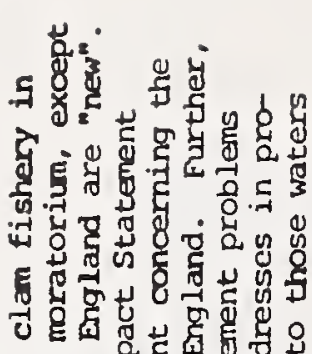

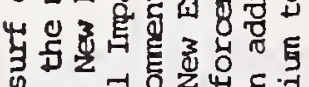
9 9.580 .50

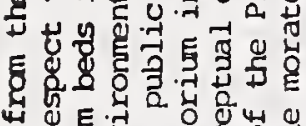
4

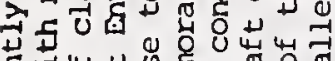

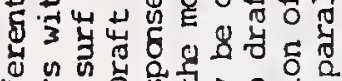

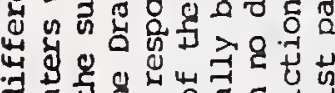

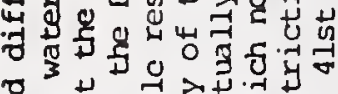

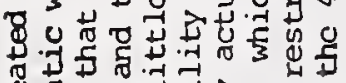

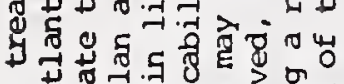

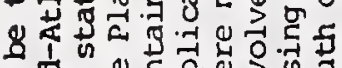

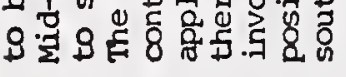

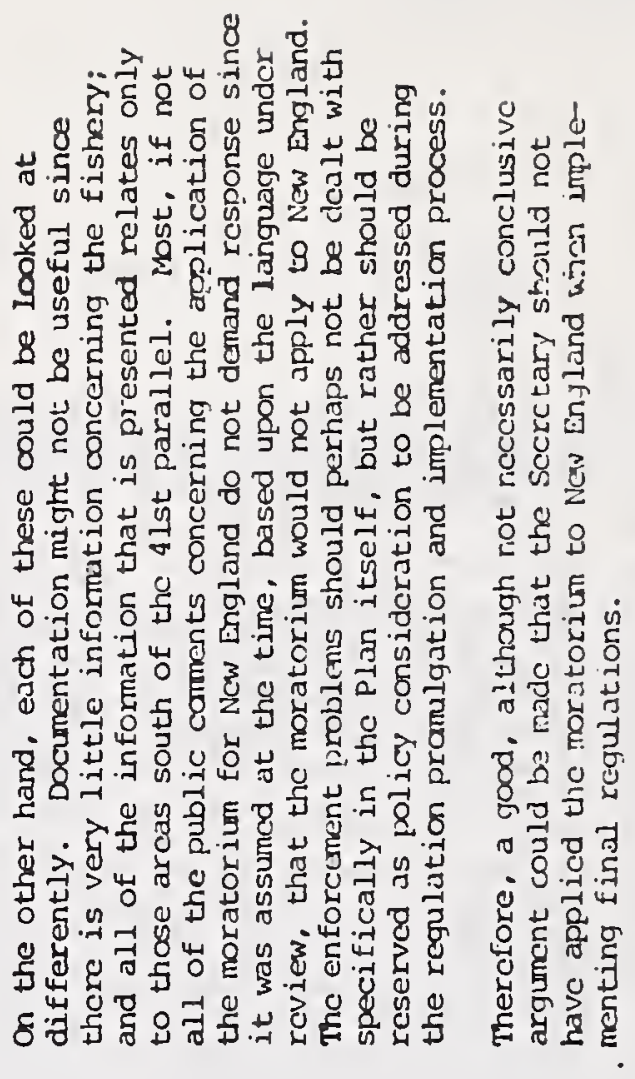

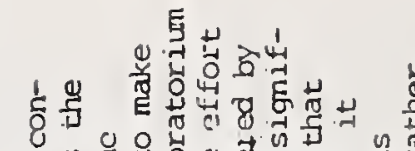

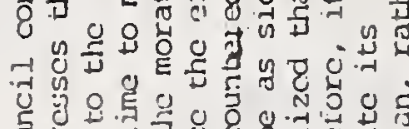

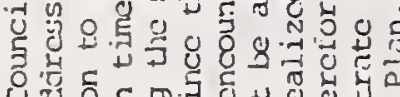

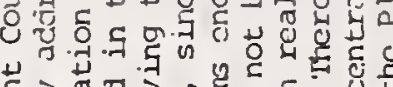

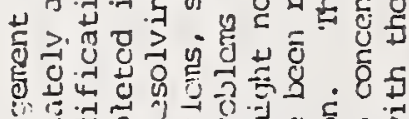

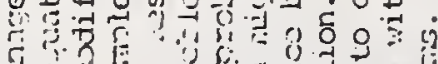

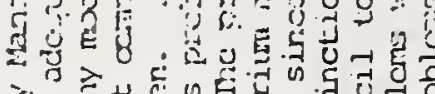

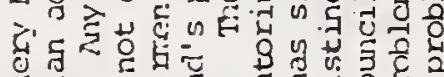

6.

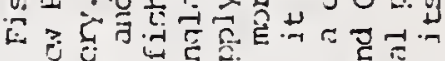

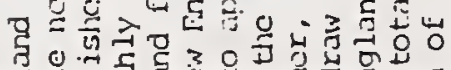

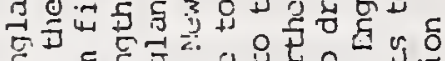

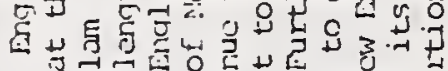

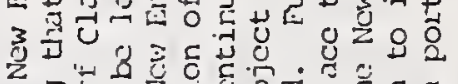

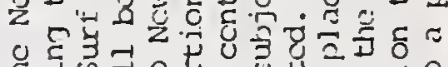

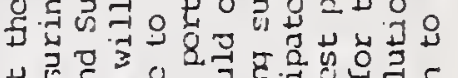

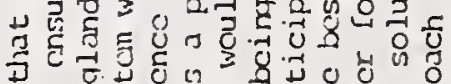
T.

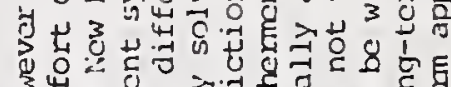

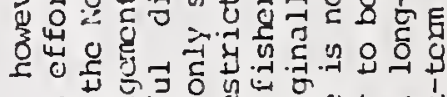

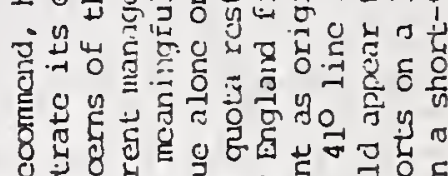

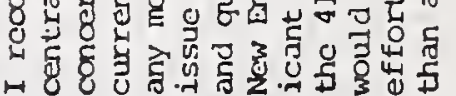

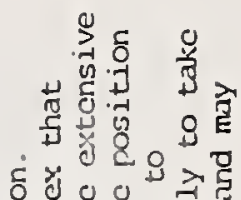

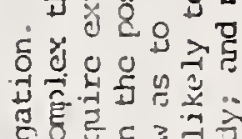

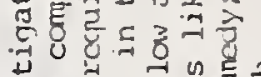

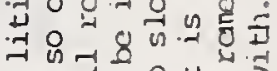

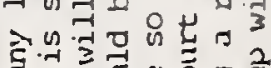

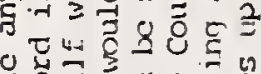
गु है 의

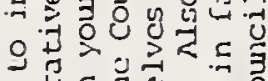

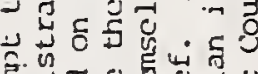

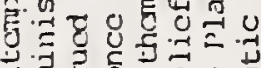
मे है है

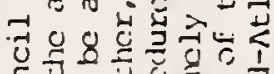

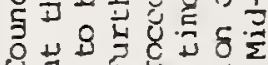
过

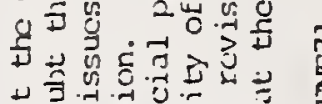

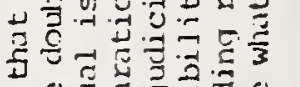
व

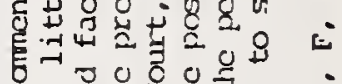
\&

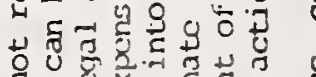

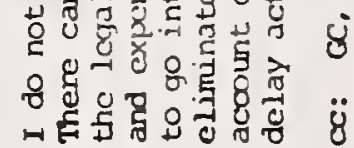
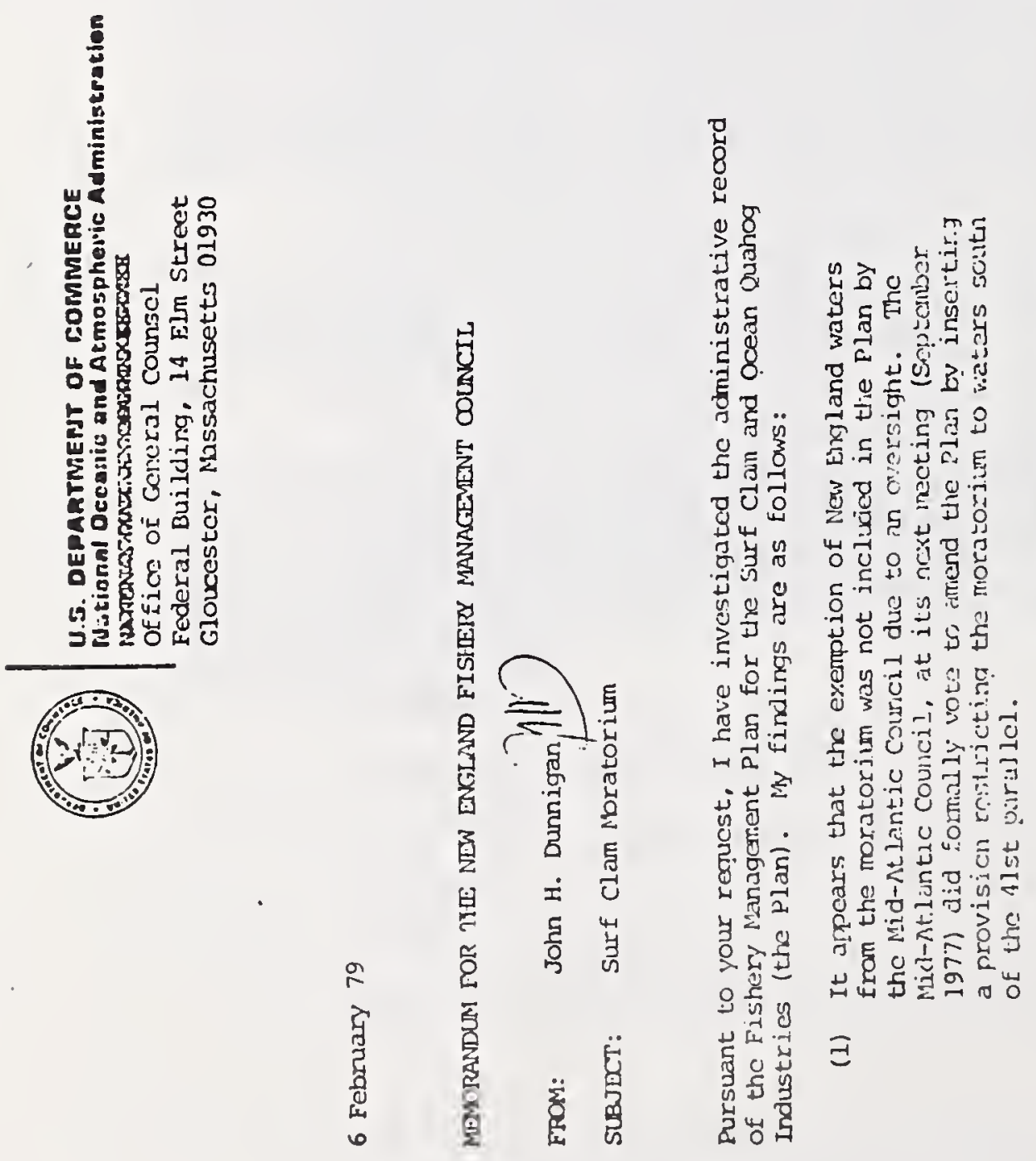

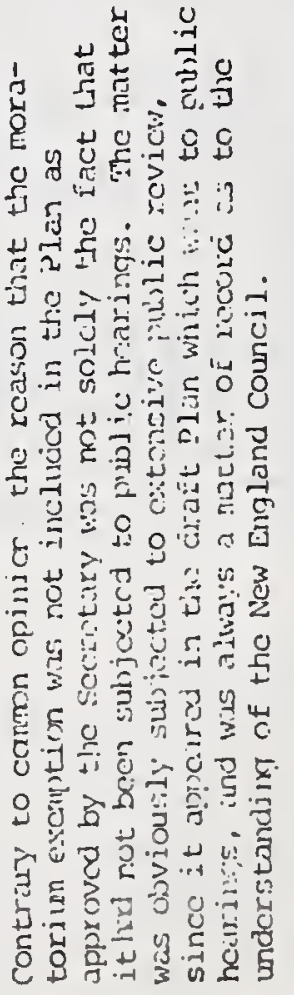

ฮิ

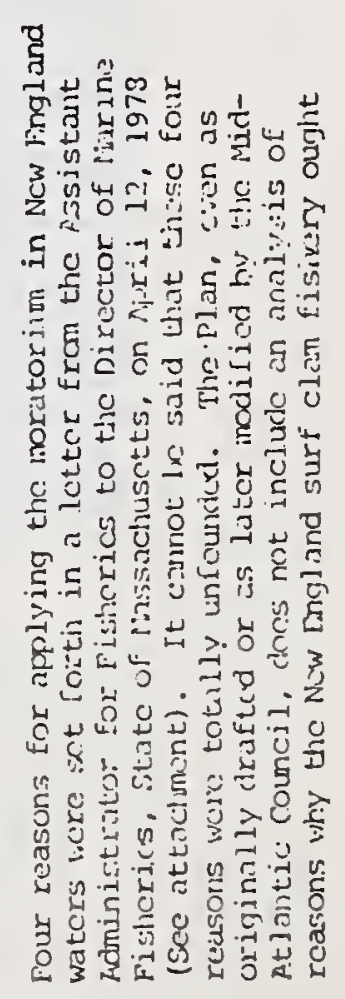

ติ 
The Council decided against litigation.

The Mid-Atlantic Council produced a draft Amendmert \#2 to the Surf Clam/Ocean Quahog Plan in June 1979. The MidAtlantic position on the New England recomendation was:

"the Council has been considering the recommendation of the New England Fishery Management Council that a special regime be established for the surf clam fishery in New England. There has been much discussion since the original EMP was developed relative to the New England surf clam fishery, whether it differed enough from the Mid-Atlantic fishery to warrant a separate regime, and if so, what form that separate regime should take. After much consideration, the Mid-Atlantic Council has developed an alternative for the management of the surf clam fishery in New England. The alternative provides for the establishment of a separate management regime in New England, that is, the area north of the dividing line between the Mid-Atlantic and New England Fishery Management Councils (see figure). In the northern area the moratorium on entry of vessels into the surf clam fishery and the effort and gear restrictions would not be in effect. A quota of 200,000 pounds of surf clams would be set for that area. The New England quota would be in addition to the quota for approximately 30 million pounds of surf clams set in the amended FMP in the Mid-Atlantic. When half of that quota would be caught, the effort restrictions operating in the Mid-Atlantic area would be imposed. Any harvest of surf clams from the northern area would not be charged against the Mid-Atlantic surf clam quota. Vessels entering the New England fishery under this special provision would not be entitled to fish in the Mid-Atlantic area and would not accrue any rights to a future direct allocation system that might be established. Vessels with permits issued pursuant to the moratorium established by the original Surf Clam and Ocean Quahog Industries FMP would be permitted to fish in the northern area, but their landings would be reported separate from their Mid-Atlantic landings and would not count toward any possible future direct allocation system base calculation."

In response to the draft, specifically the 200,000 pound proposed quota and effort restriction when one half of the quota was taken, both Massachusetts and Rhode Island submitted comments on the draft to the Mid-Atlantic Council (see July 9 and 23 correspondence). Both states noted the disincentive 


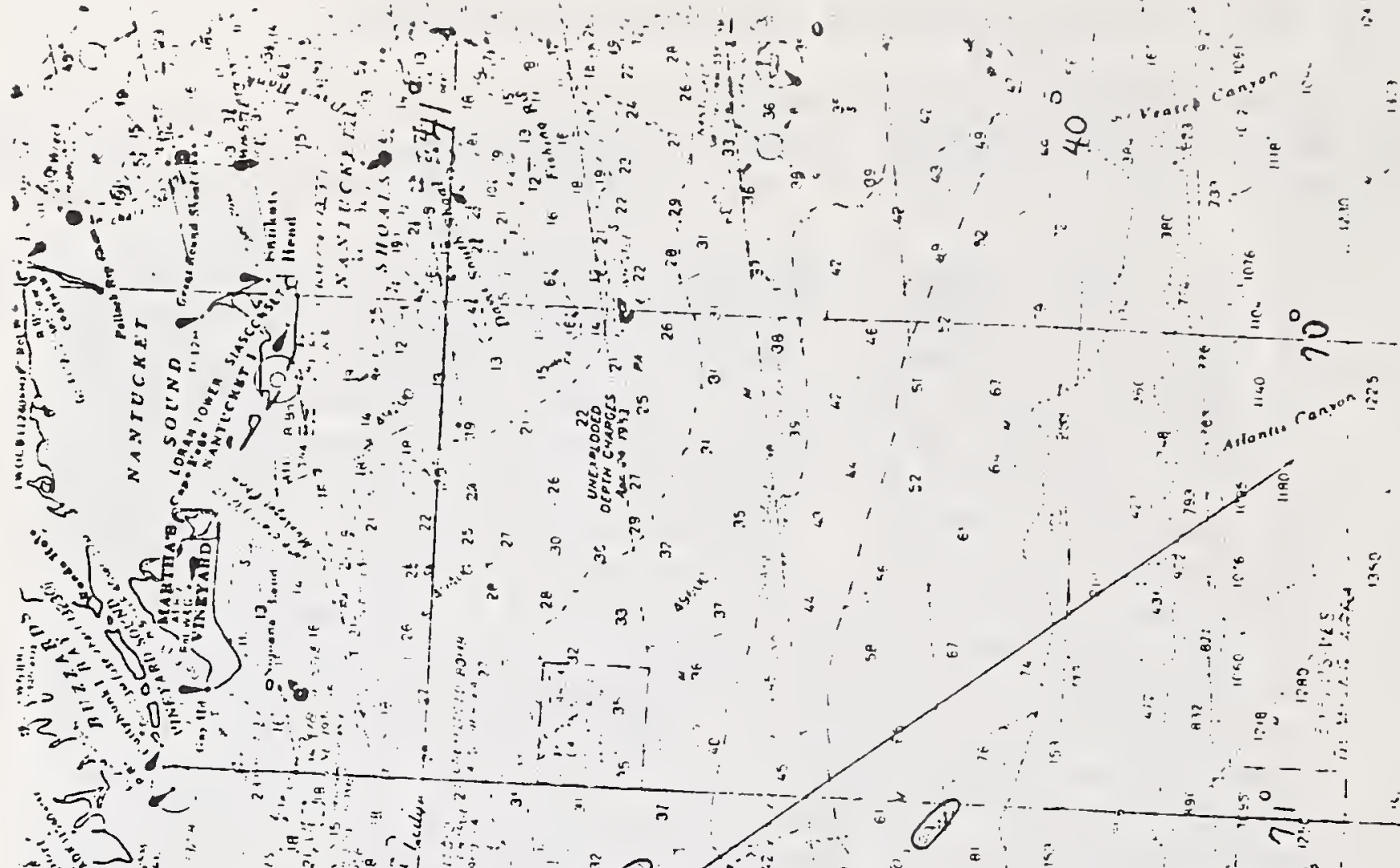

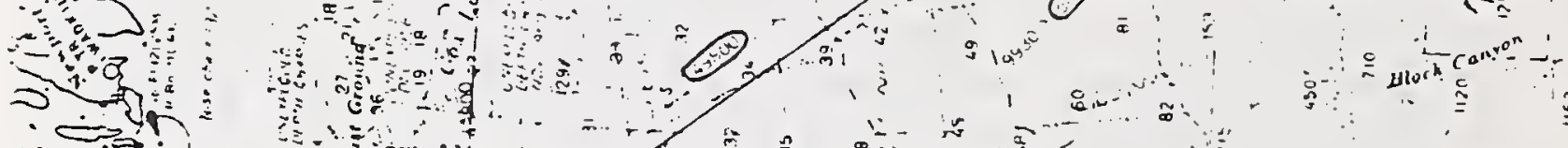
$\therefore$ 进

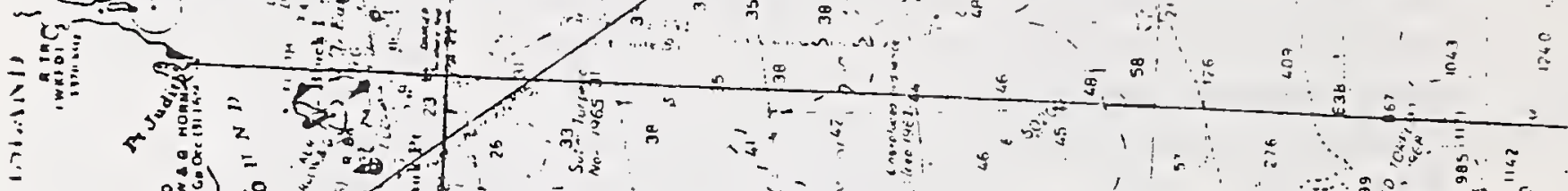

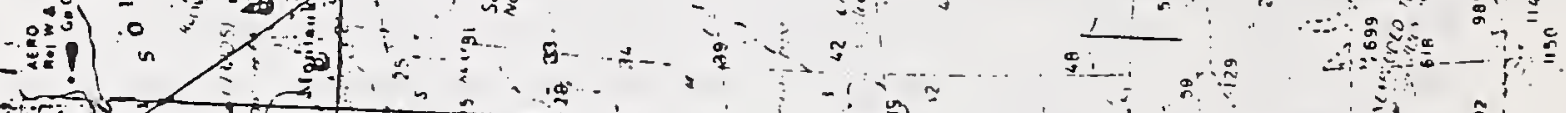

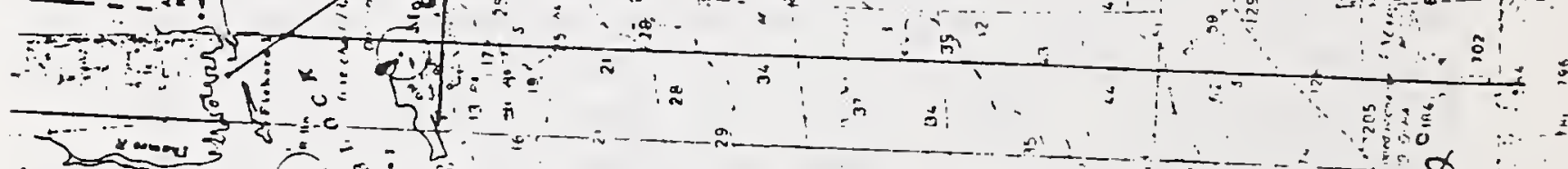

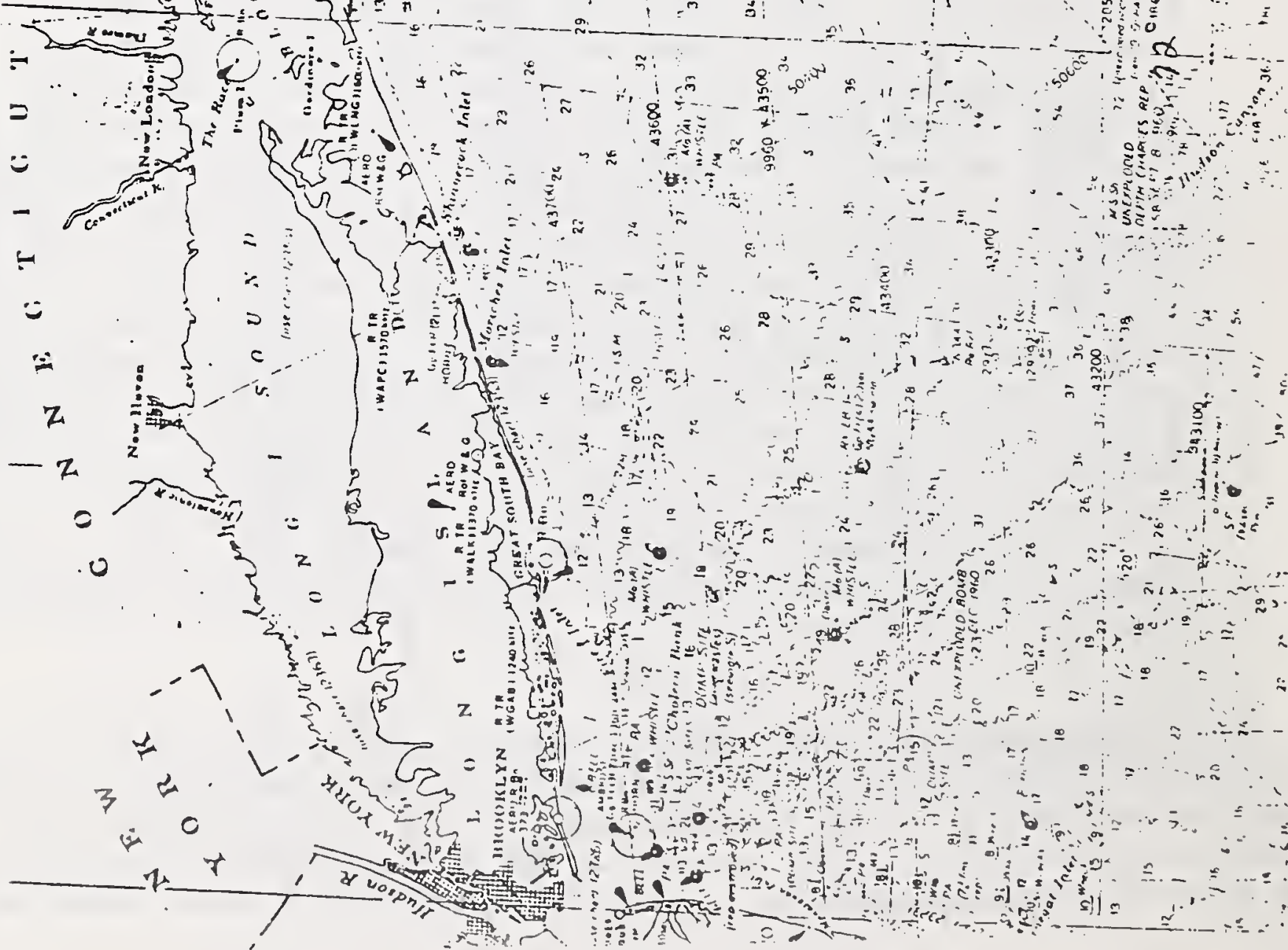




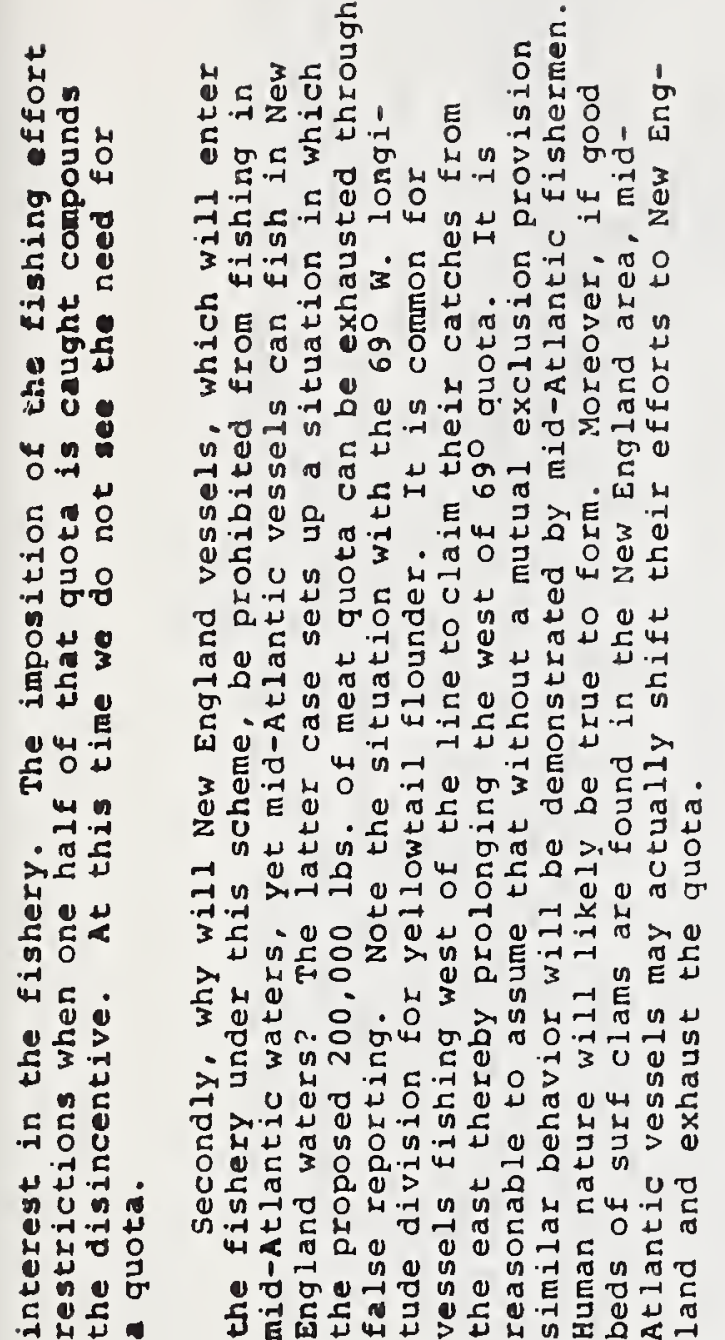

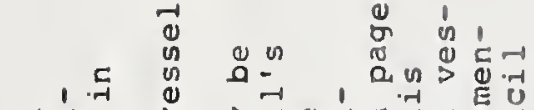

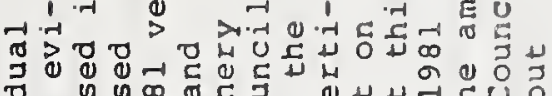

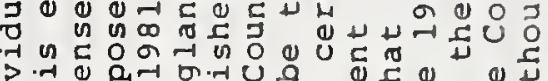
年-

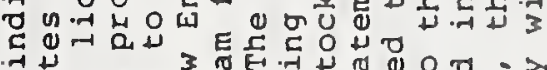

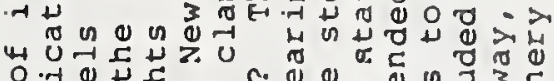

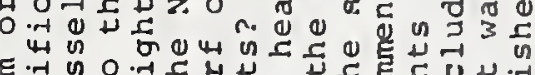
E 出出 $>$ ग क r

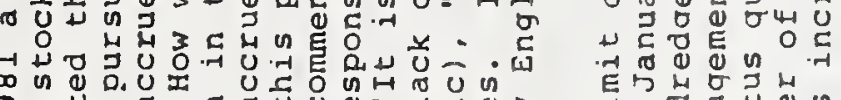

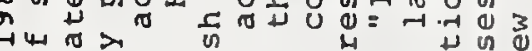

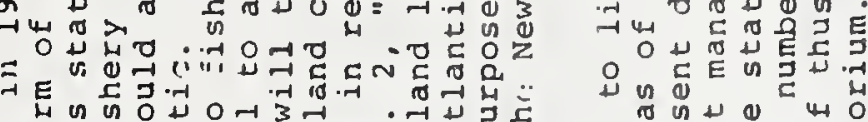
ᄃ

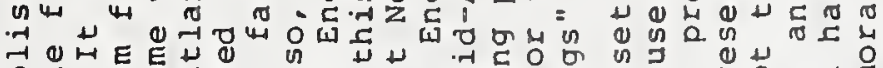

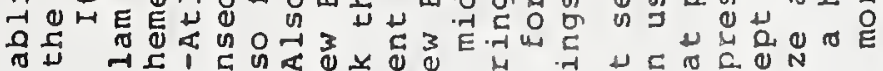
出 ब.

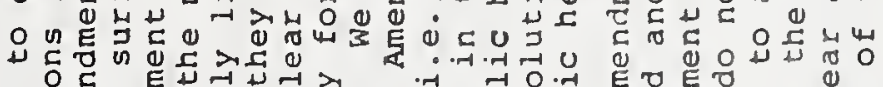

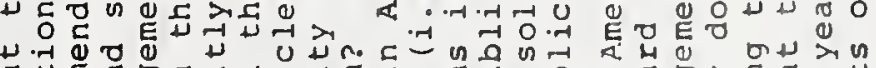

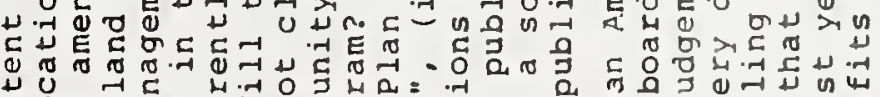
C 。 ब

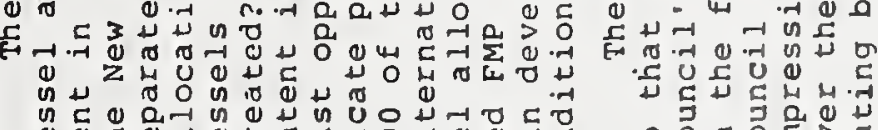

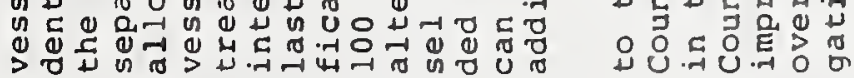

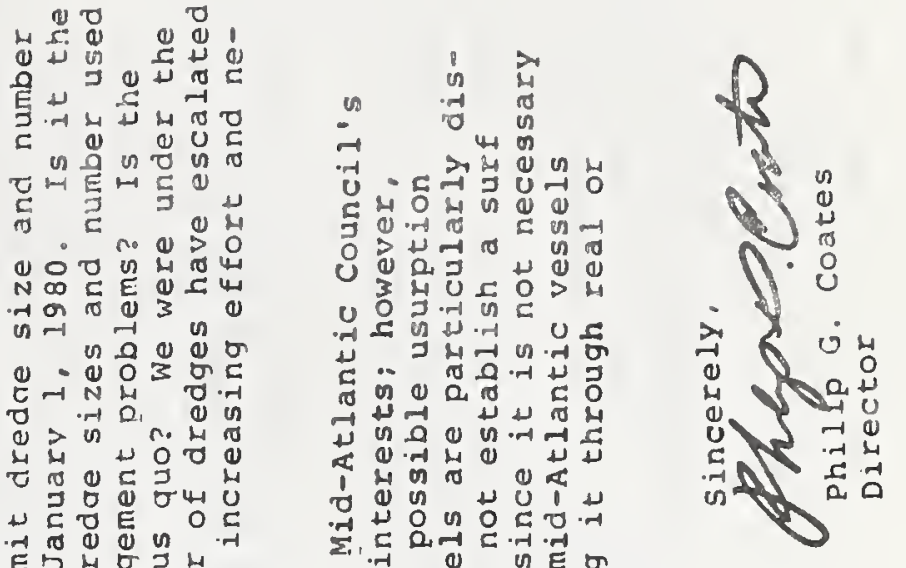
2.

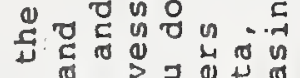

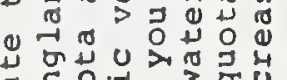

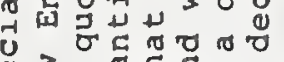

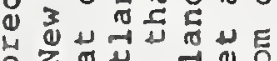

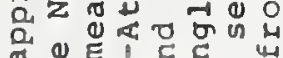

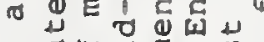

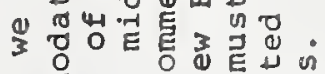

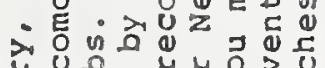
प्र Eี

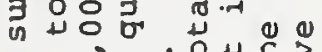

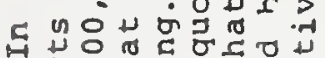

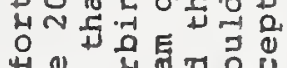

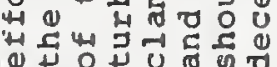

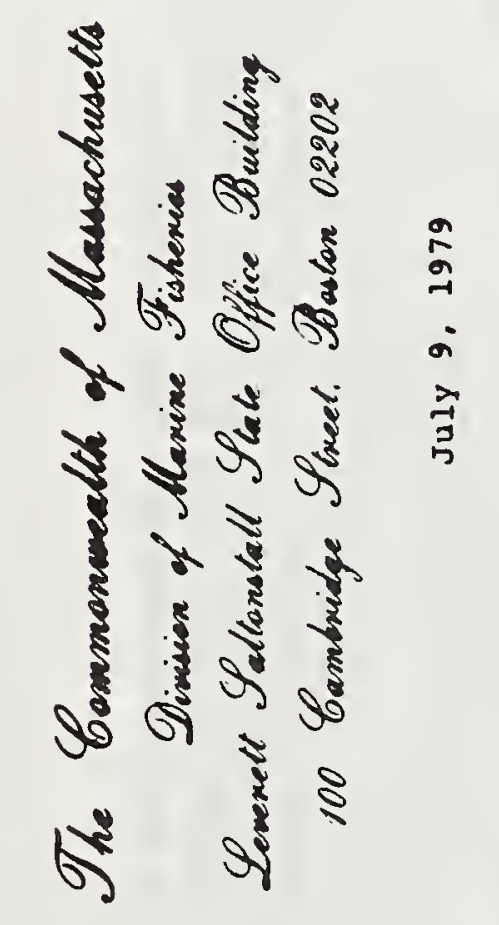
मेण 4. ᄃ

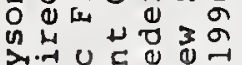

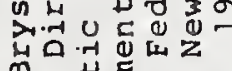

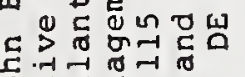

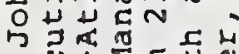
J

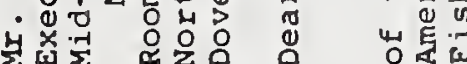

동 $\frac{0}{4}$ ?

î

त.

00

군요

₹थ

出否

ᄃ도을

$\rightarrow$ Q

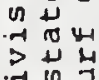

an n.

出

范胳出

至

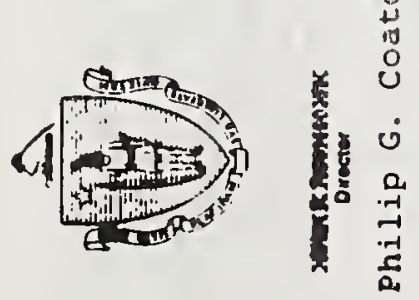

责云

न- $\begin{array}{ll}-\pi \\ 0\end{array}$

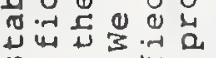

ज.

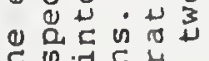

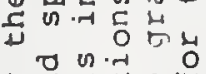

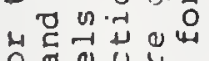

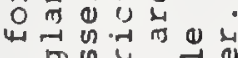

o

ow $>$ w

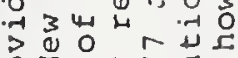

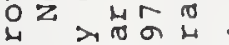

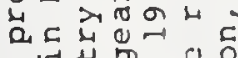

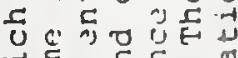

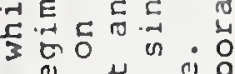

๑

D

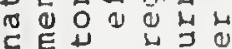

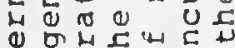

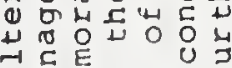

刃

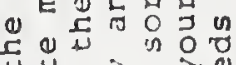

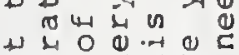

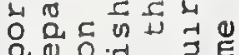

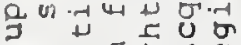

का

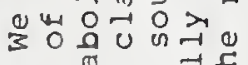

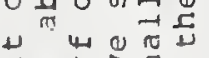

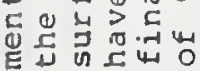

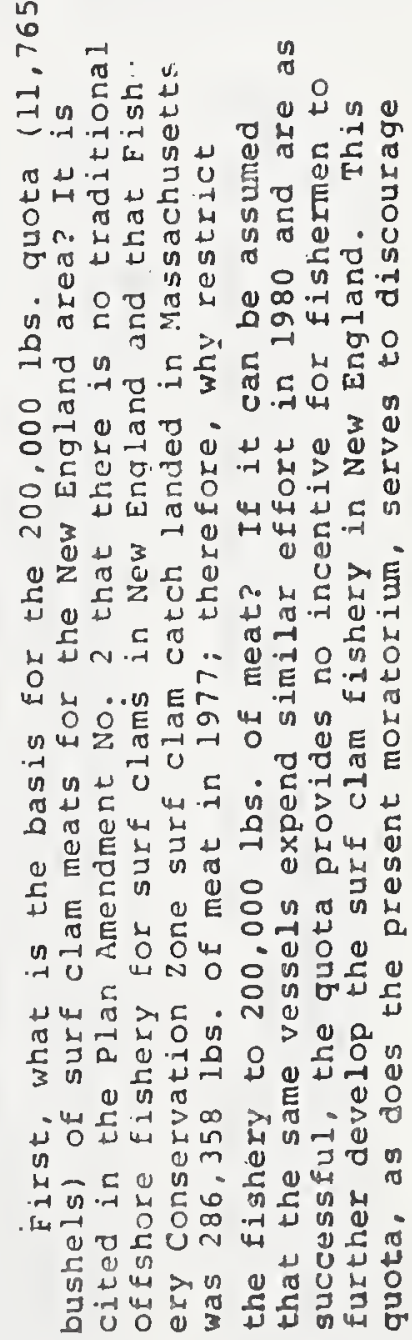




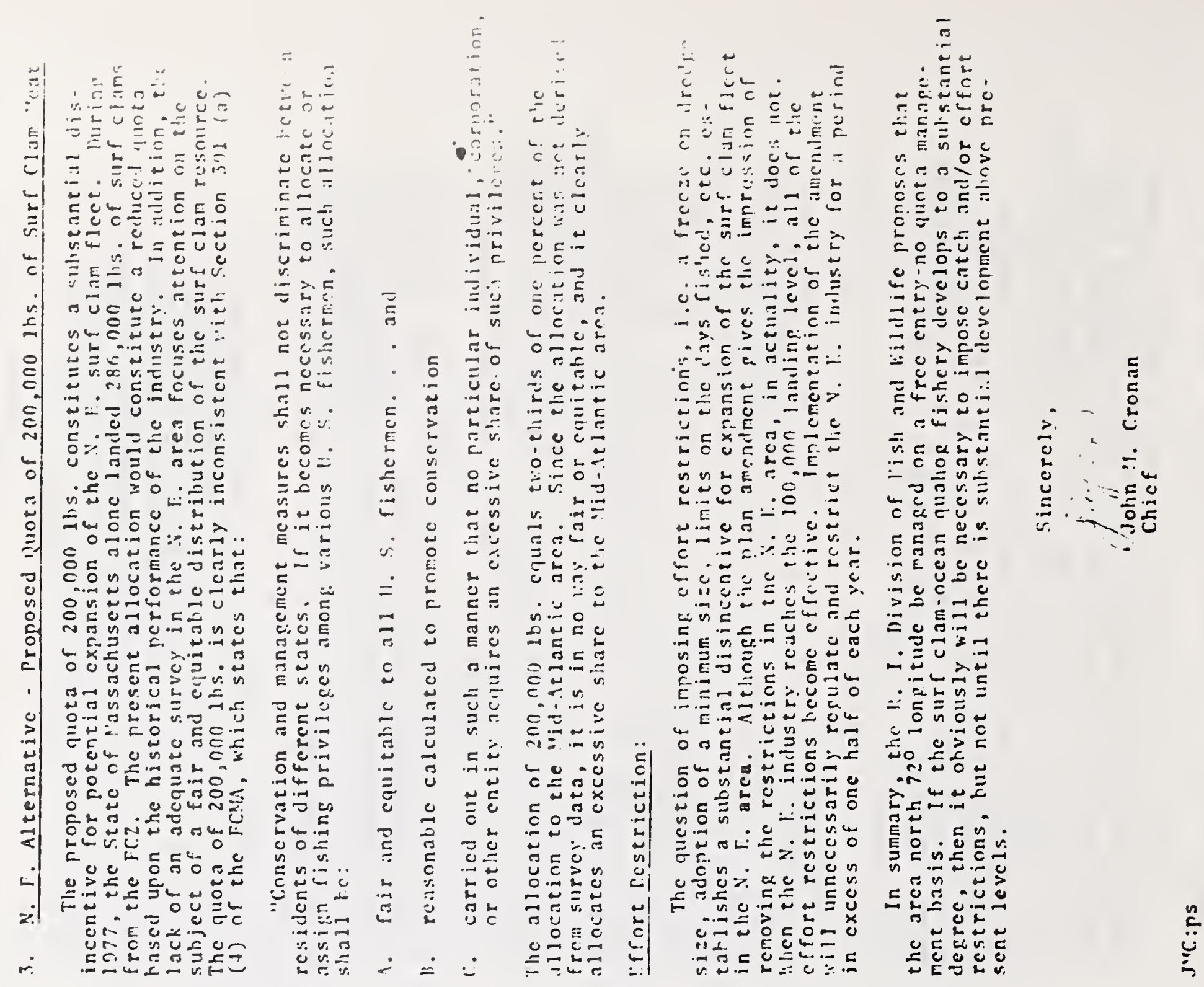

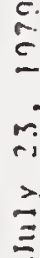

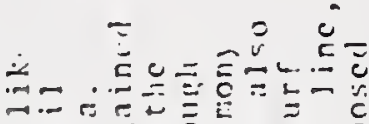

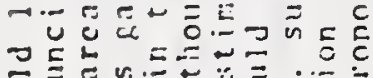

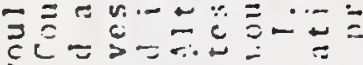
-

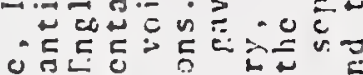
0 政 $e=5$

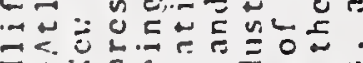

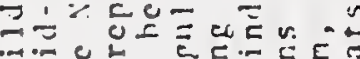

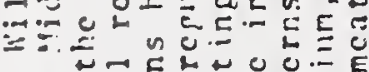

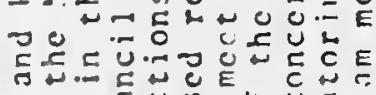

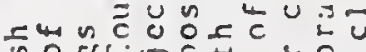

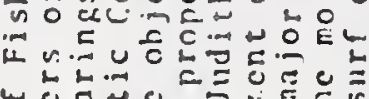

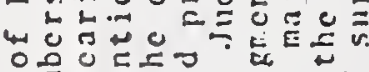

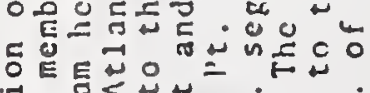

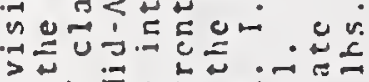

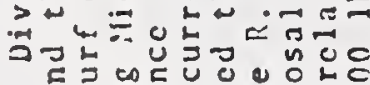
解舟 .4 舟它

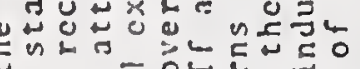

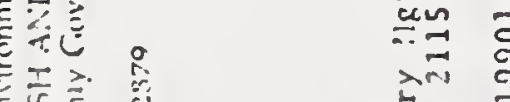

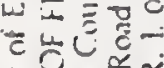

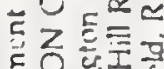

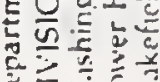

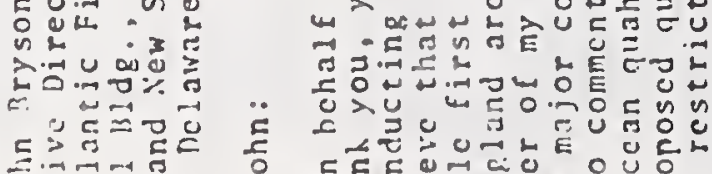

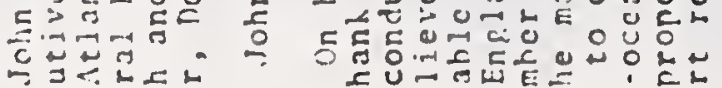

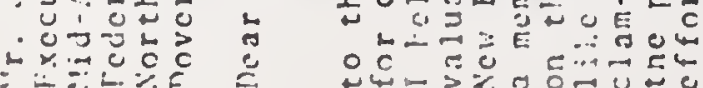

$\therefore: \stackrel{c}{0}$ : $\because \quad \equiv$

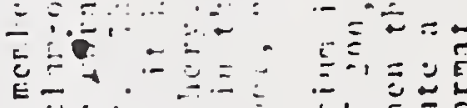

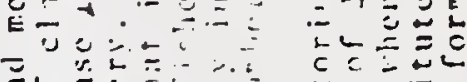

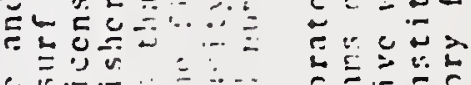
con

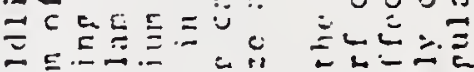

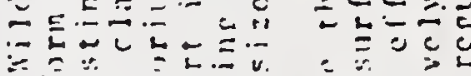

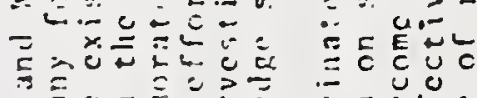

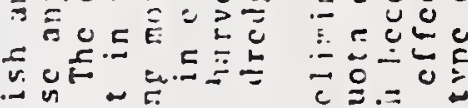

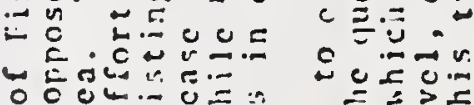

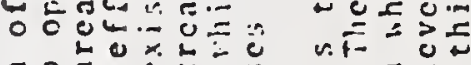

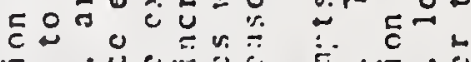

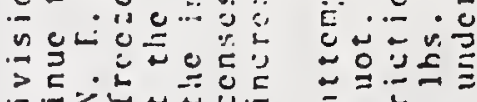

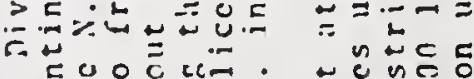

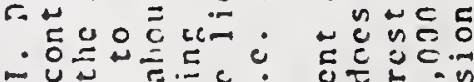

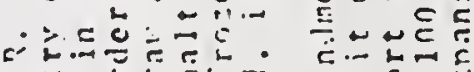

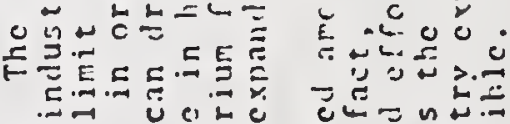

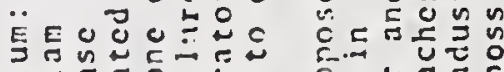

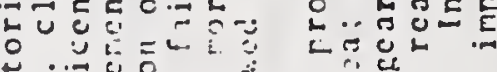

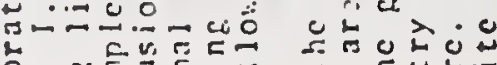

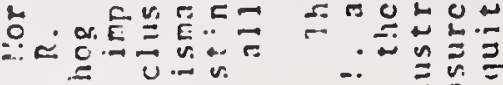

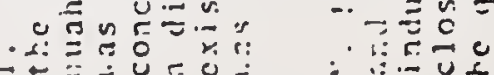

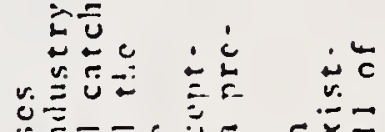

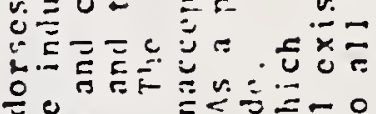

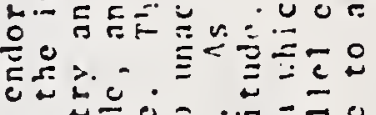

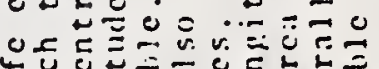

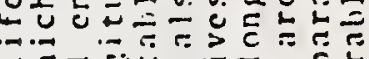

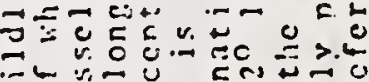

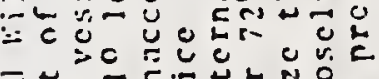

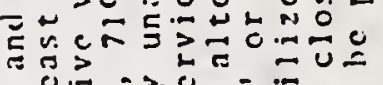

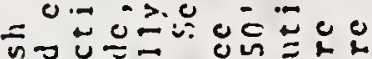

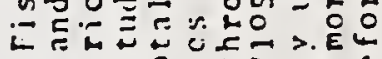

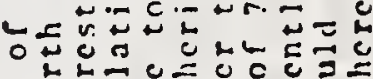

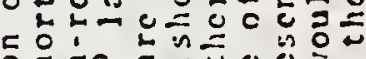

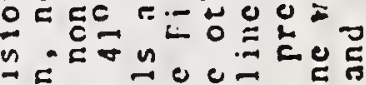

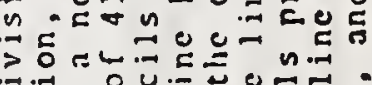

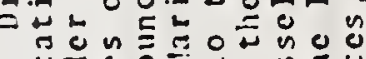

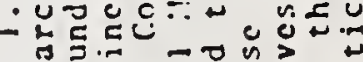

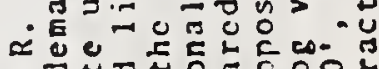

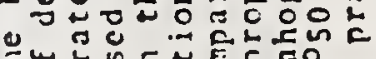

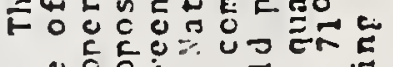

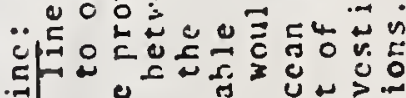

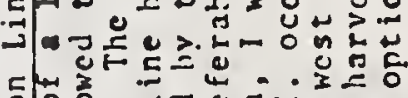

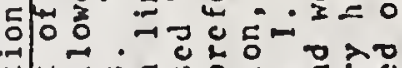

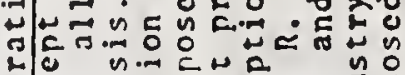

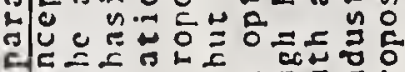

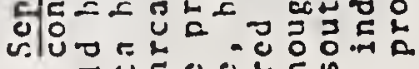

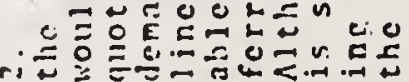




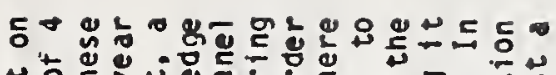

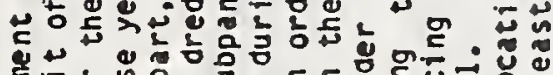

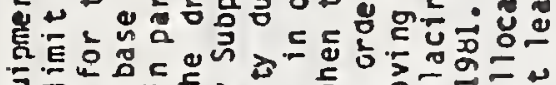

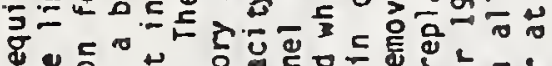

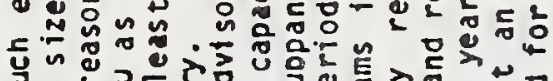

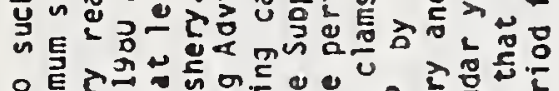

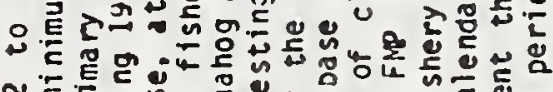

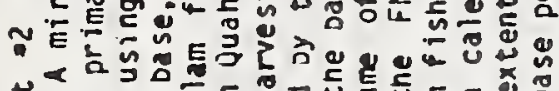
先

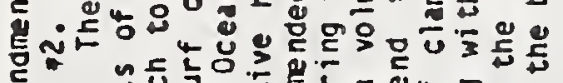

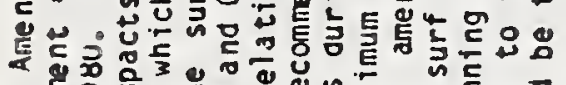

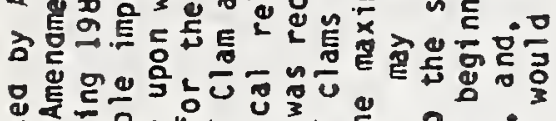

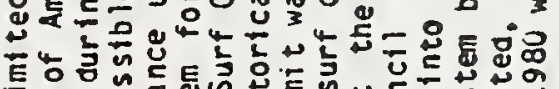

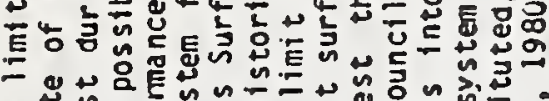

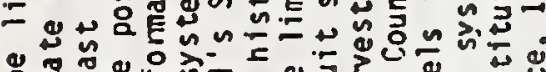

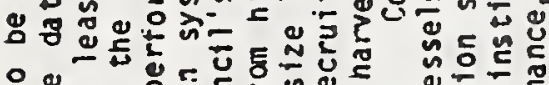

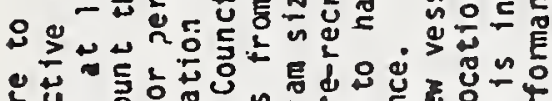

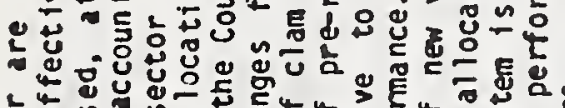

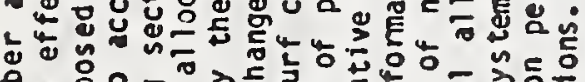

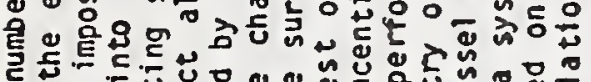

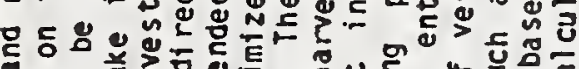

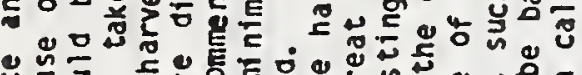

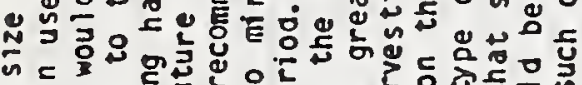

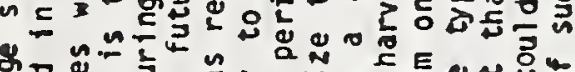

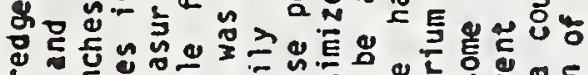

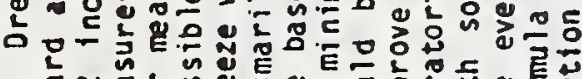

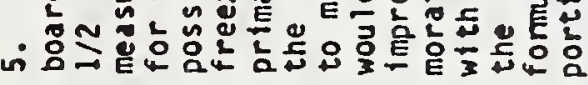

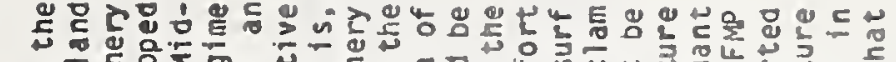

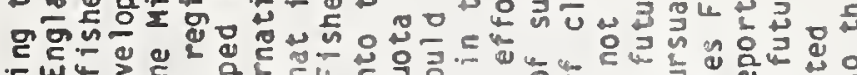

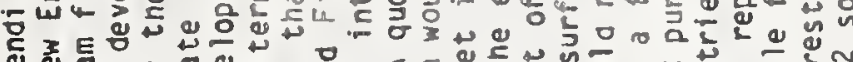

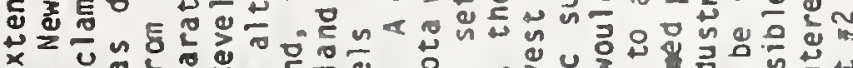

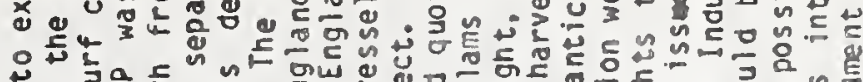

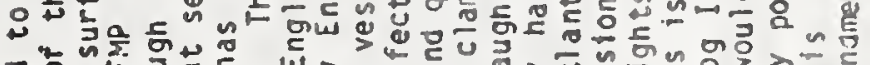

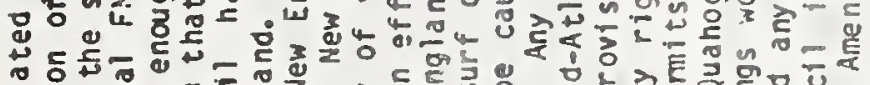

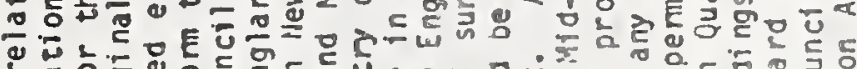

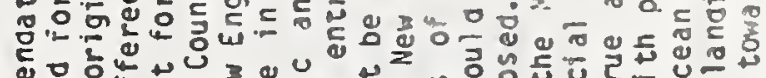

管

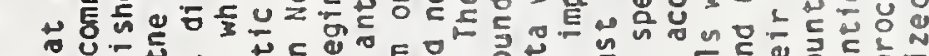

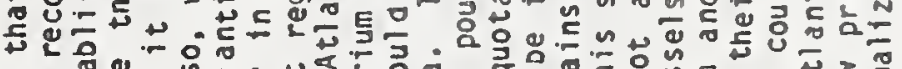

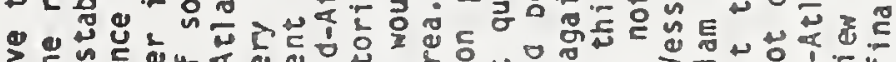

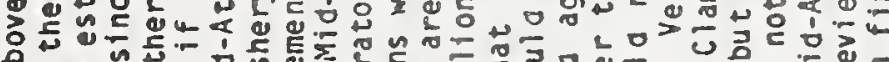

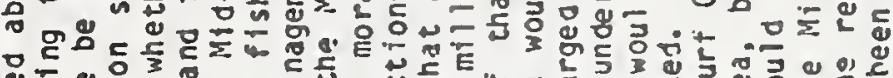

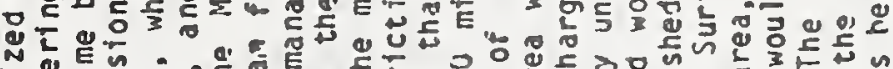

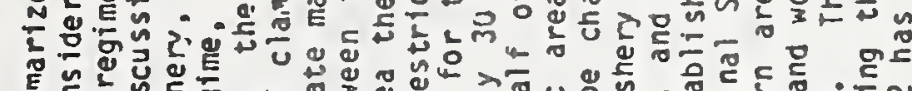

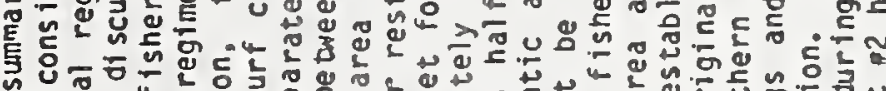

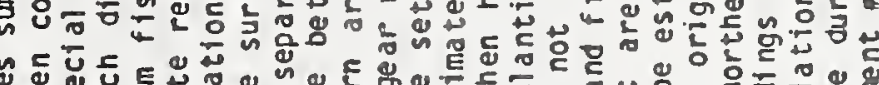

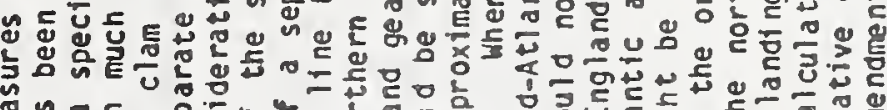

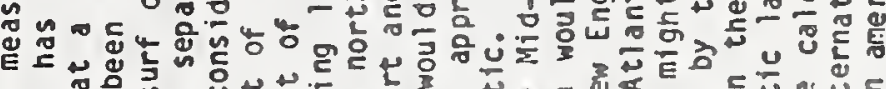

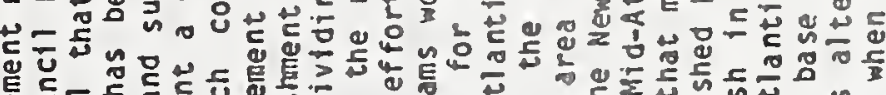
尊訶

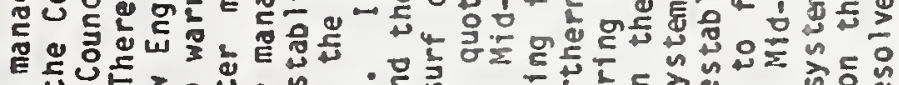

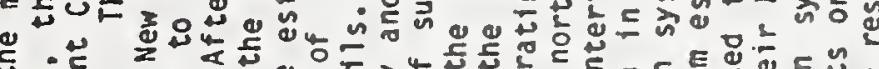

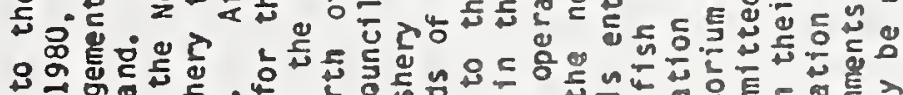

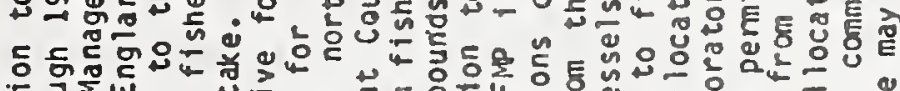

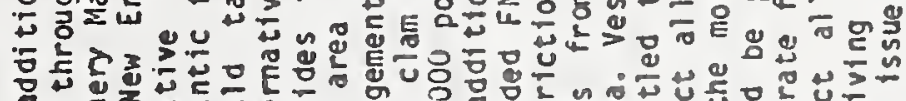

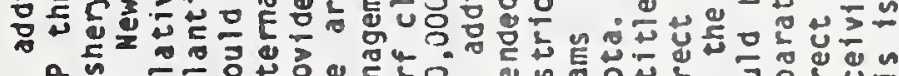

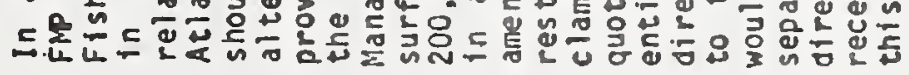

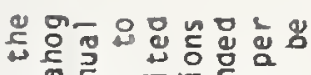

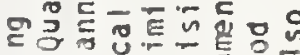

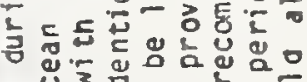

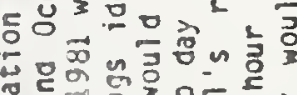

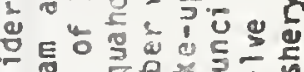

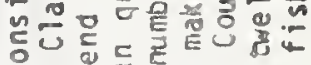

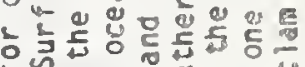

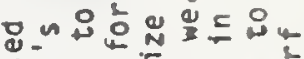

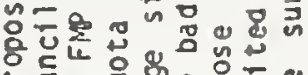

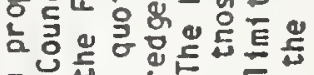

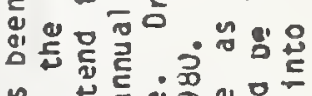

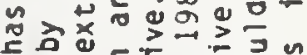

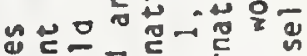

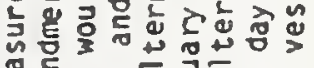

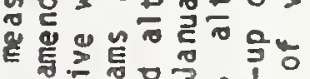

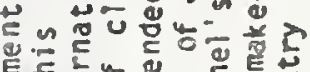

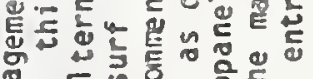

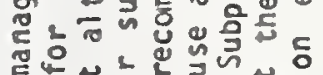

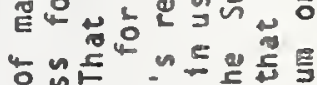
등.

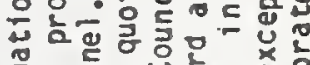

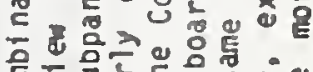

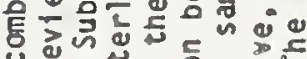

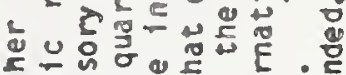

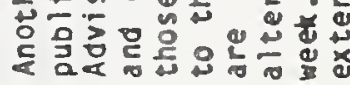

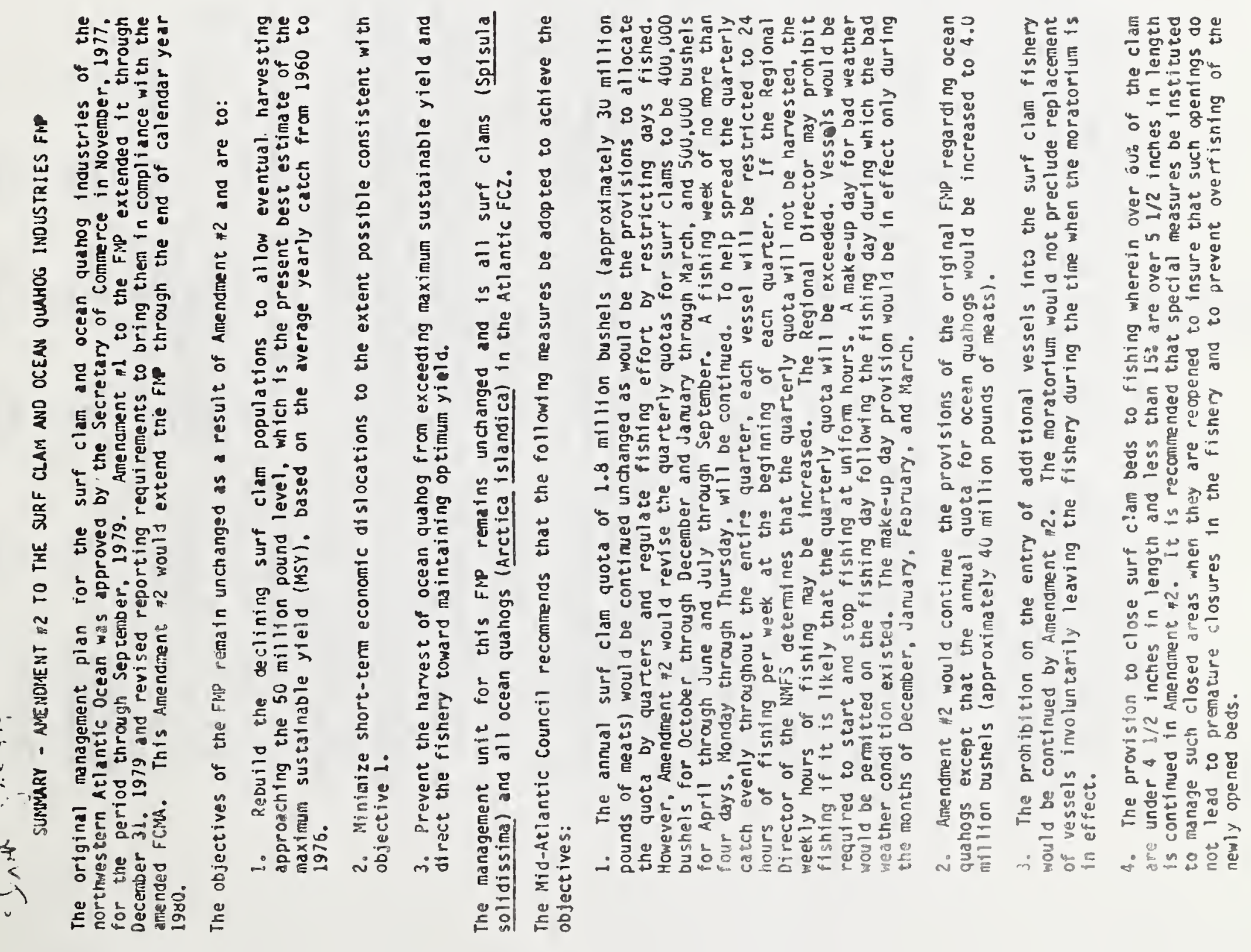




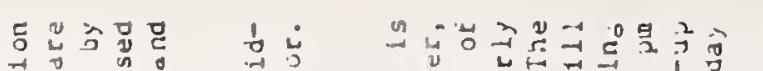

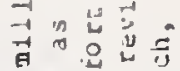

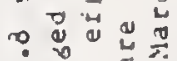

-

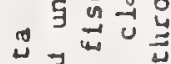

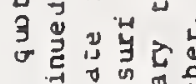

己

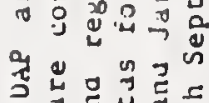

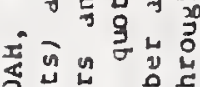

ठี

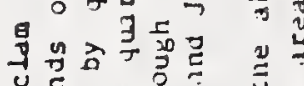

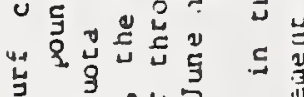

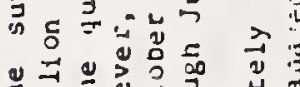

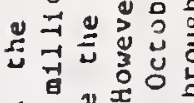

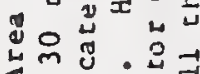

< 절

प्य

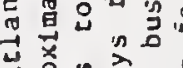

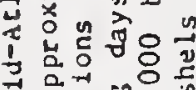

돈

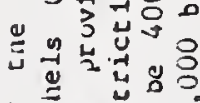

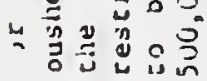

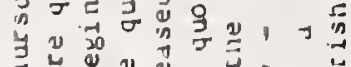

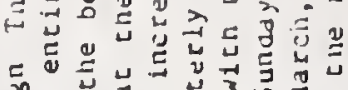

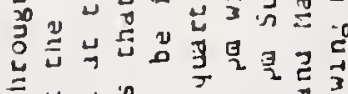

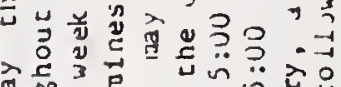

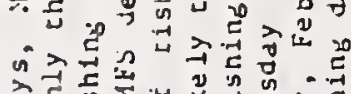

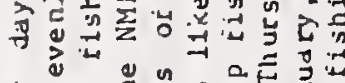

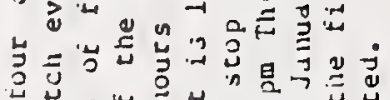

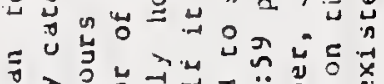

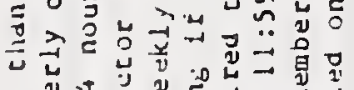

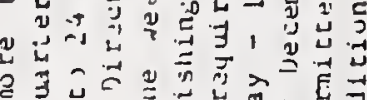

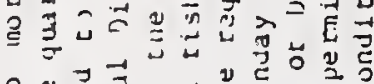

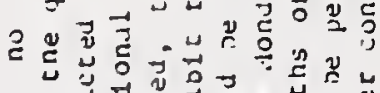

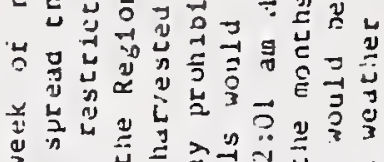

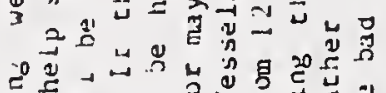

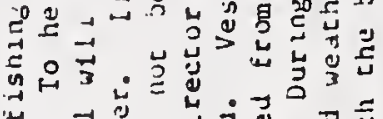

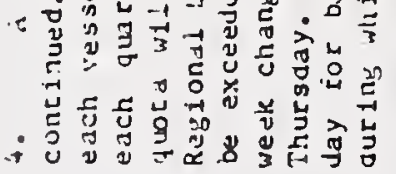

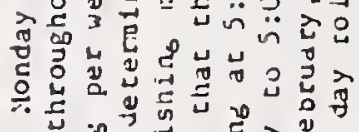

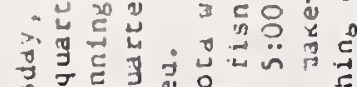

4.

$y=$

范

$\exists$

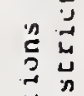

岕

造总

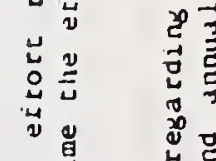

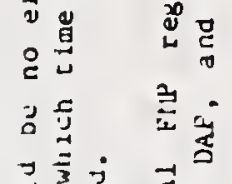

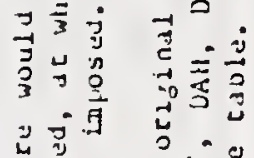

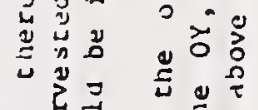

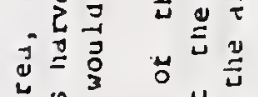

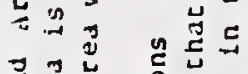

过

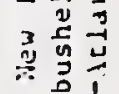

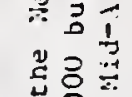

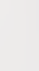

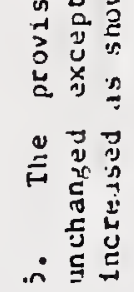

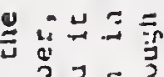

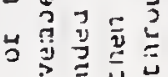

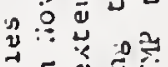

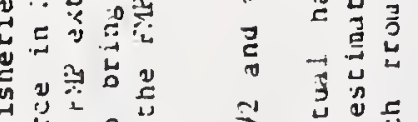

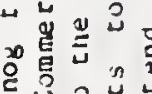

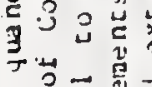

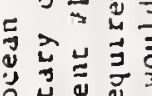

药

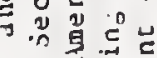

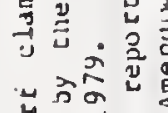

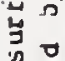

पं

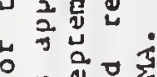

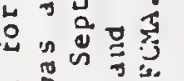

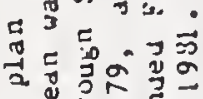

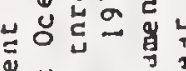

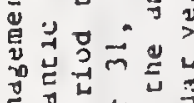

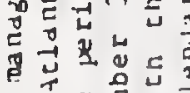

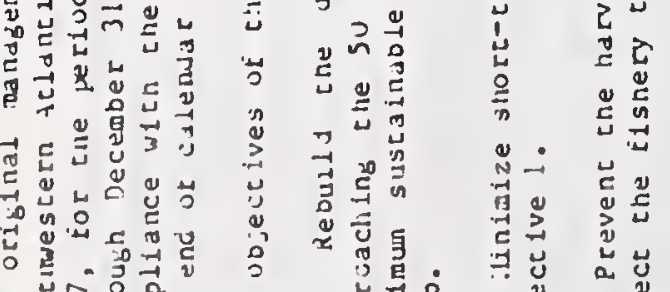

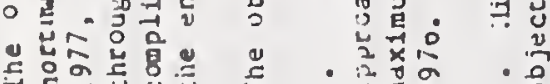

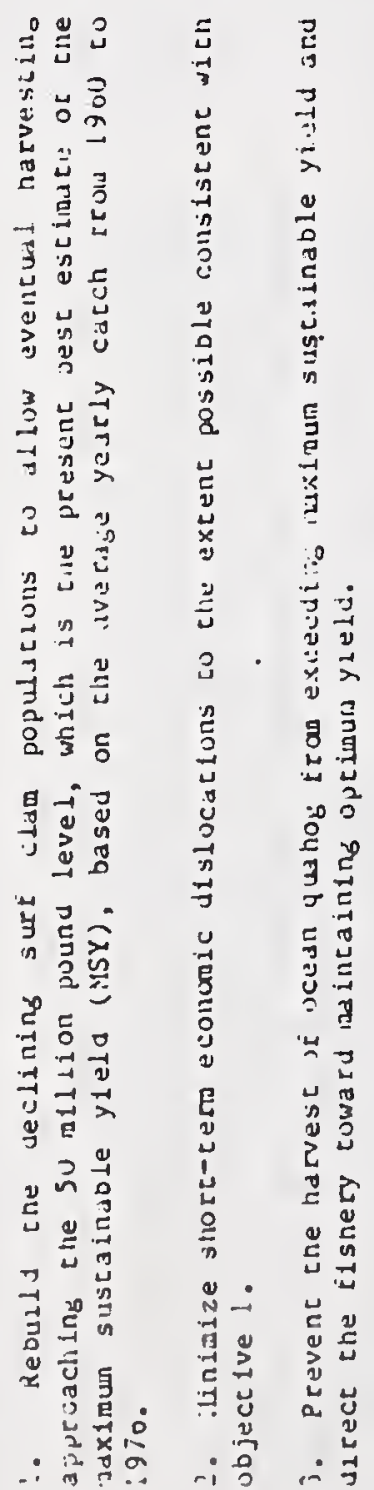

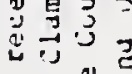

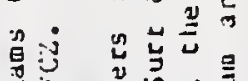

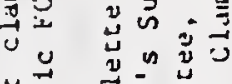

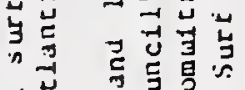

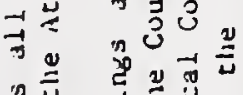

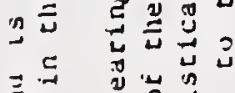

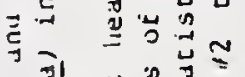

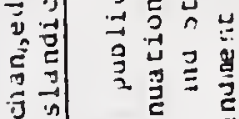

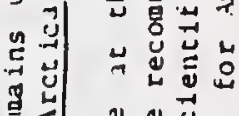

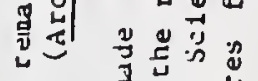

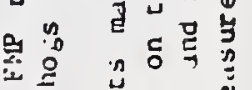

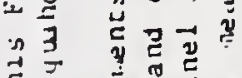

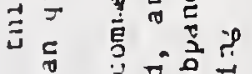

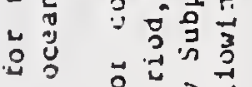

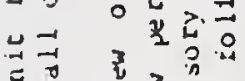

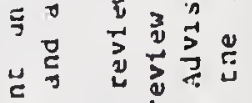

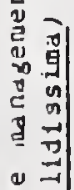

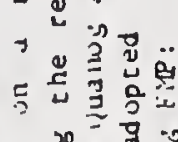

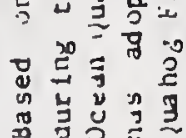

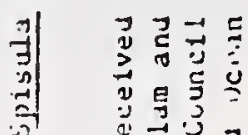

与ी

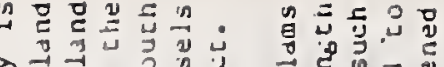

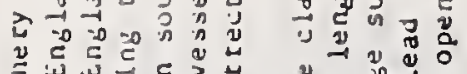

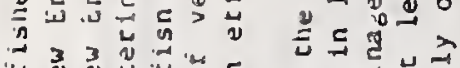

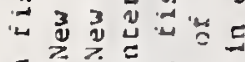

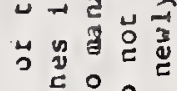

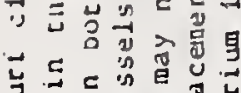

ว้

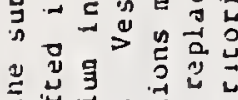

今

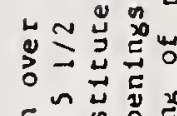

-1

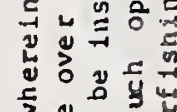

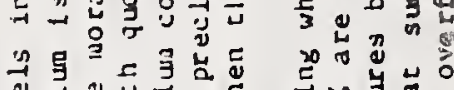

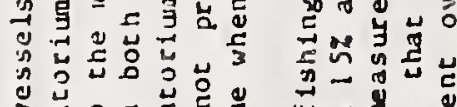

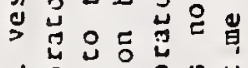

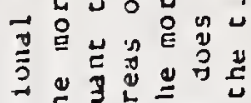

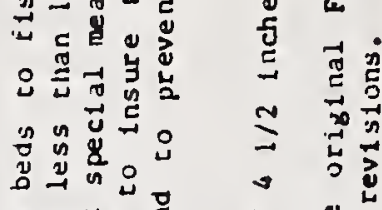

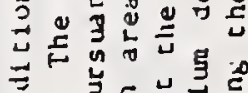

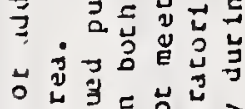

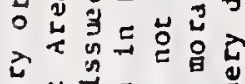

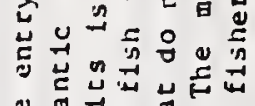

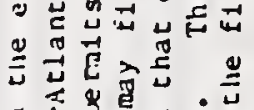

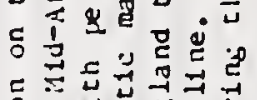

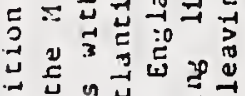

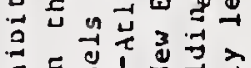

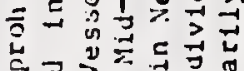

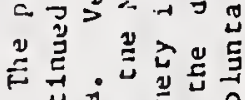

.

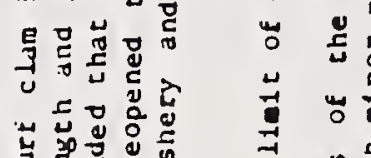

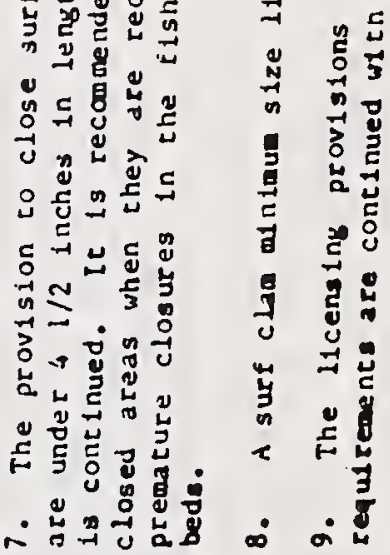

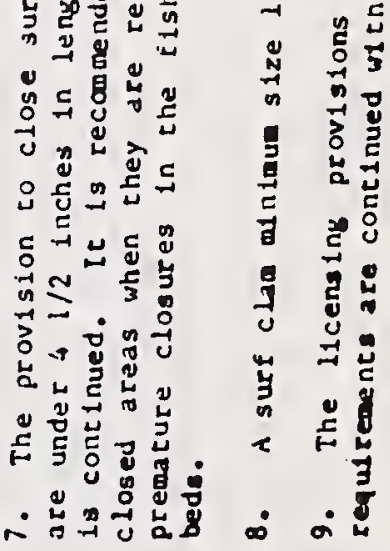

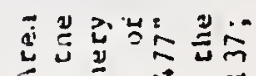

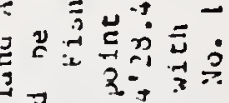

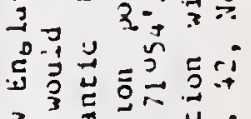

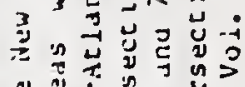

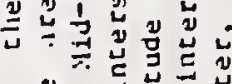

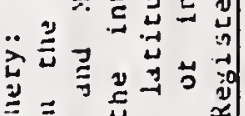

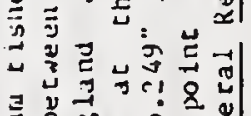

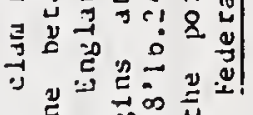

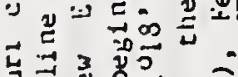

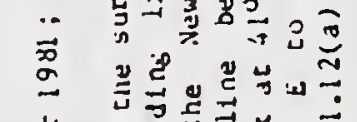

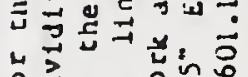

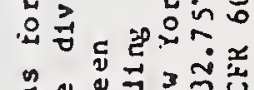

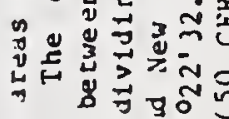

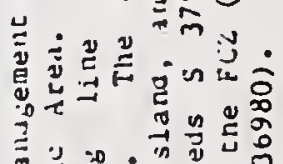

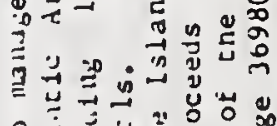

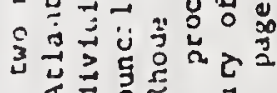

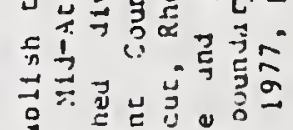

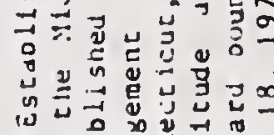

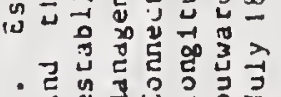

站 $=0 \quad 0=$

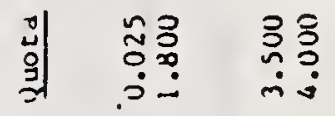

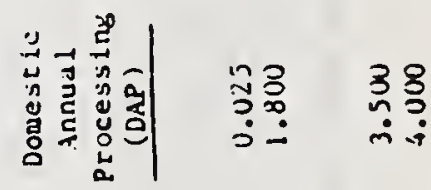

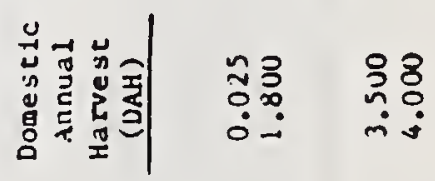

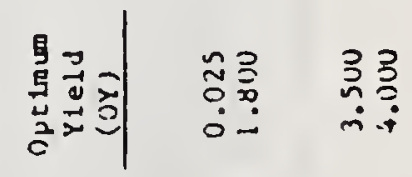

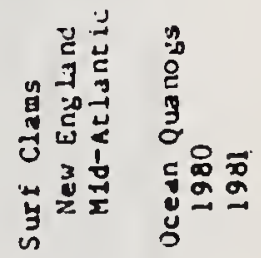


to fishermen caused by the 200,000 pound quota and effort restriction. These comments were aired at July 10 and 11 New England hearings.

The final Amendment \#2 was published in August of 1979. Plan objectives were the same. Two management areas were established using the dividing line between the New England and Mid-Atlantic Council authority as the separator. The summary of the Amendment is included here.

The major difference between the drafts and the final, as far as New England was concerned, was that the quota was increased to 400,000 pounds of surf clams. The Mid-Atlantic Council did not believe that the 400,000 pound quota of surf clam meats was restrictive on the New England fishery due to the small size of past catches from the New England region. It believed that the quota left much room for expansion. Additionally, it was very concerned over the influence of "New England clams" on market prices and feared that too high a quota would lead to adverse economic impact on MidAtlantic, as well as New England, interests. They were also concerned over the need for a foreign allocation since any unharvested New England quota, brought about by setting that quota too high, would indicate excess capacity thus obligating the secretary of Commerce to make the excess available to foreign fishermen.

The Mid-Atlantic Council appeared to make a sincere attempt to accomodate New England interests under the constraints which it had to work. While the proposed New England quota may not have been great enough to encourage expansion and growth of the New England surf clam industry in the Fishery Conservation Zone, the Mid-Atlantic Council's concerns, legal and otherwise, were appreciated. Lifting of the moratorium was at least a good first step, especially since no one was sure of the fishery's growth potential. However, the Mid-Atlantic Council did feel that if the New England industry could harvest the 400,000 pounds quota, then the New England Council would have had solid grounds on which to base an argument for an increased quota and more offshore survey work by NMFS to better assess the resource and its potential.

At December 1979 Council meetings it was reported that the Mid-Atlantic Council was investigating ways to remove the moratorium from their area as well. They were looking at schemes such as stock certificate programs. Apparently, vessels which formerly sold their surf clams to smaller processors were selling to larger processors because a higher price was offered. Smaller processors were therefore finding it difficult to acquire an adequate supply to meet their needs and wanted to bring in their own boats by removing the moratorium. 
The Mid-Atlantic Council developed another amendment to its Surf Clam/Ocean Quahog Plan - Amendment \#3 (January 1981) to revise and extend the Plan indefinitely. Proposed objectives were:

1) Prevent the exploitation of these resources from exceeding those levels which reduce the probability of successful recruitment to the fisheries.

2) Provide the greatest degree of flexibility to all harvesters of these resources consistent with the attainment of the other objectives of this Plan.

3) Optimize yield per recruit.

4) Increase understanding of the conditions of the stocks and fishery.

The Mid-Atlantic Council decided to propose as its preferred course of action:

1) Continue the provision to close areas with large numbers of small surf clams; impose a $51 / 2$ " surf clam size limit; continue annual and quarterly quotas; and, continue the effort restriction in the existing Plan. The ocean quahog regime would be continued unchanged.

2) Revise the fishing week, bad weather make-up day, and effort restrictions.

3) Create separate management areas for reopened surf clam areas.

4) A proposal to choose between either a) a permit limitation system in the Mid-Atlantic surf clam fishery or b) a ceiling on numbers of surf clam permits. Valid permits in 1981 would be valid in 1982. Tó retain a permit a vessel must harvest 8,000 bushels of FCZ clams (surf clams or ocean quahogs) annually. The total number of permits may increase or decrease by 5 for every 5 percent increase or decrease in optimum yield. No permit shall be revoked if the vessel caught 8,000 bushels annually.

May hearings were scheduled to discuss these proposed Plan changes.

At May 1981 New England Council meetings the Plan's proposed strategies were discussed. According to one summary of the hearing: 
"There were 15-20 people attending the hearing. There was good representation from both Massachusetts and Rhode Island from both the harvesting and processing sectors. My general observation is that most of the comments received were negative concexning most of the proposals. Negative comments were directed at the minimum size of 5 1/2" applying to both New England and Mid-Atlantic areas.

The proposal to create a 25,000 bushels quota for New England waters is opposed. There has never been an adequate survey of the New England waters. Since there has not been any survey work done, a number of people questioned why we had a quota at all.

The major objection related to the limited entry provisions. It should be eliminated. Those in attendance were against both licensing proposals."

According to another summary:

"I don"t think anybody has a lot of scientific data on ocean quahogs. We took the position that we would be very supportive of time/area closures for as long a period as is necessary to protect the resource. We see no other reason at the moment for the kind of complicated mess they are in down there. We think these are purely economic measures, and they are discriminatory. The Plan sets some precedents which we feel are undesireable. I would echo the plea that this council take some action and say it is not in favor of the Plan as it stands."

The Council initially decided to communicate its opposition to several of the proposals contained in the proposed Surf Clam/Ocean Quahog FMP Amendment. The specific items of concern related to regulations affecting the New England area and were as follows:

Surf Clams:

1. $51 / 2^{\circ 10}$ minimum size

2. 25,000 bushel fixed quota

3. Inposition of effort restrictions when $1 / 2$ of the quota has been harvested

Iicensing provision $5 \mathrm{a}$ and $5 \mathrm{~b}$ in the current amendment 
Ocean Quahogs:

1. inclusion of the New England area in the 4-6 mil. bu. quota

2. possible effort restrictions in New England when $1 / 2$ of the quota has been reached

In addition, it shall be the position of the council to respectfully request that the Mid-Atlantic Council initiate the following actions:

Surf Clams: The New England area should continue as a separate management unit without any other restriction. New England vessel licenses subject to the moratorium should be able to retain these fishing privileges in the Mid-Atlantic area without the requirement to land minimum quantities. In addition, the council endorses the proposed survey in the New England area.

Ocean Quahogs: A separate management area should be established for ocean quahogs in the New England area similar to that established for surf clams. There should be no quota or other effort restrictions imposed on the New England ocean quahog fishery.

The New England Council respectfully requests that the Mid-Atlantic Council appoint two New England fishing industry representatives to the surf clam and ocean quahog advisory subpanel.

However, at the urging of the Regional Director, the Council agreed to take an alternative action. The Regional Director had stated:

"I have some personal concerns with the motion the way it is. What I would suggest is that we defeat or withdraw the motion and that the Chair authorize our Surf Clam Committee to meet, sit down and work with the Mid-Atlantic Council staff and put together comments for their consideration. My concern is that, as I see the motion, I don't think it will have a significant impact on the Mid-Atlantic Council. These people can come back and let us know the results of the meeting and then if our efforts did not work, we can send a letter. I would like to see the Councils work together to build a compatible plan. I would recommend defeating the motion and taking that course of action."

Results of the Surf Clam Committee's meeting with the Mid-Atlantic's Surf Clam Committee were related at the June 
1981 meetings. Apparently the Mid-Atlantic Surf Clam Committee was receptive to many of the New England Council's suggestions. One Council member, Jacob Dykstra, stated:

"I would Iike to commend the Mid-Atlantic for apparently being responsive to the expressed desire of this council. On the other hand, I would like the record to show that as far as I am concerned, I don't think there is any concrete biological need for limited entry in this fishery. It seems to me this limited entry scheme is discriminatory. Apparently there are a lot of surf clams available. I would vigorously support closures that would protect small clams or for any biological reason. But, I still very much fail to see any biological reason for the limited entry, and I think it is discriminatory."

The Amendment \#3 system to limit permits in the MidAtlantic area surf clam fishery as a replacement to the moratorium was not accepted by NOAA. In lieu of this limited entry scheme the Department of Commerce extended the moratorium on entry of vessels into the Mid-Atlantic area. The limited entry scheme had evolved to allow one new permit for every four permits expiring.

The eventual provisions of Amendment \#3, which were still in effect as of the end of 1982, are provided in a Mid-Atlantic Council summary of its Surf Clam/Ocean Quahog Plan. 


\section{SURF CLAM AND OCEAN QUAHOG PLAN}

The original Plan was approved by the Secretary of Commerce in November, 1977, for the period through September 1979. Amendment $\| 1$ extended it through 31 December 1979, and revised reporting requirements to bring them in compliance with the amended MFCMA. Amendment $1 / 2$ extended it through the end of calendar year 1981. Amendment $\mid 3$ extended the Plan indefinitely and revised it.

The objectives of the Plan are:

1. Rebuild the surf clam populations to allow eventual harvest approaching the 50 million pound level, which is the estimate of maximum sustainable yield over the range of the resource, based on the average yearly catch from 1960 to 1976.

2. Minimize economic dislocation to the extent possible consistent with objective 1 and encourage efficiency in the fishery.

3. Prevent the harvest of ocean quahogs from exceeding maximum sustainable yield and direct the fishery toward achieving Optimum Yield.

4. Provide the greatest degrees of freedom and flexibility to all harvesters of these resources consistent with the attainment of the other objectives of this Plan.

5. Optimize yield per recruit.

6. Increase understanding of the conditions of the stocks and fishery.

The management unit is all surf clams and all ocean quahogs in the Atlantic FCZ.

There is a 5:5" minimum size limit for surf clams in the Mid-Atlantıc Area.

Quotas are set annually through a consultative process. For surf clams, the values are between l.o and 2.9 million bushels iapproximately $30-50$ million pounds of meats) for the Mid-Atlantic Area and between 25,000 and 100.000 bushels (approximately 425,000 -1.7 million pounds of meats) in the New England Area. For ocean quahogs, the values are between 4.0 and 6.0 million bushels $\{40-60$ million pounos of meats .

1r. the Mid-Atiantic Area, surf clam quarterly quotas are equal. The bad weather make-up cay is in eifect during November through April. The fishıng week begins at 6:00 am Sundav and ends at 6:011 pm Thu:stav, but may cegin at 1::00 am Sunday under certain conditions. Effort restrictions are set by the Fe-isanal Directo: so as to insure fishıng througnout a quarter with the minımum cnance of clo:sure whu $\equiv . s 0$ mınimizıng the eifort changes during the quarter.

In the New Engtario Area, wher. 50\% of the annual surf clam quota has been caught, the Regıonal Cires:ar may reduce the rumber of davs per week, or establish authorized periods. ouring which surf clam fisr.ınc is permitteo.

When $50^{\circ} \circ$ of the ocean quatıg quota has been caught, the Regional Director may reouct the nurt:e: $=:$ days ouring which fishing for ocean quanogs is allowed.

Areas ciosed for containing concentrautons of small surf clams, when recpenec. have allowable =-: - - :ps separate ircm trip oberali guo:a and appropriate effort restrict:ons will be :mfosec in such areas : $: \cdots:$ ? that the harves: oi the aliowable catch extenos throughout a freoetermined tume period. Fisher- - requireo to aovise ivivif $S$ if they want to fish in a reopened area.

Amenoment "3. as aoopteo or the Council. incluoeo a system to limit permits in the Mid-Atlanti: ziscz

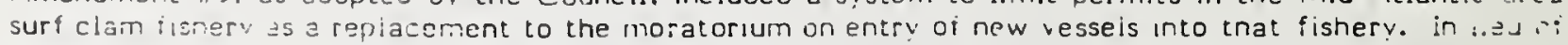

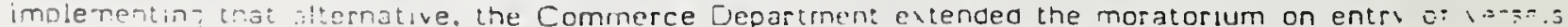
into the dic--riantic Area surf clam fishery. The Council has tegun consıeration of ways to resc... problem. 

